University of South Carolina

Scholar Commons

2014

\title{
The Constitutional Limit of Zero Tolerance in Schools
}

Derek W. Black

University of South Carolina - Columbia, blackdw@mailbox.sc.edu

Follow this and additional works at: https://scholarcommons.sc.edu/law_facpub

Part of the Constitutional Law Commons

\section{Recommended Citation}

Derek W. Black, The Constitutional Limit of Zero Tolerance in Schools, 99 Minn. L. Rev. 823, 2014.

This Article is brought to you by the Law School at Scholar Commons. It has been accepted for inclusion in Faculty Publications by an authorized administrator of Scholar Commons. For more information, please contact digres@mailbox.sc.edu. 


\title{
Article \\ The Constitutional Limit of Zero Tolerance in Schools
}

\author{
Derek W. Black
}

I. The Current Crisis in Discipline 832

A. The Rise and Breadth of Expulsions and Suspensions

B. The Causal Explanation for Increased Expulsion and Suspension

C. The Rationale and Effectiveness of Zero

Tolerance and Harsh Discipline

II. The Courts' Grand Constitutional Intervention and

Silent Withdrawal from School Discipline .................... 841

A. The Goals of Goss $v$. Lopez ................................... 841

B. The Flaws of Goss $v$. Lopez ................................... 844

1. The Assumption of the "Benevolent

Administrator"

2. Indefinite and Substanceless Standards ........... 847

3. Goss as the First Step in an Unfolding Judicial Project That Never Came To Be

C. Reducing Disciplinary Hearings to a Sham

D. Substantive Due Process: A Claim Never Fully Considered

E. The Increasing Disengagement of Courts in Discipline

III. The Mandate of Substantive Due Process: Accounting for Relevant Distinctions, Innocence, Individualized Factors, and Deliberation.

A. Treating Significantly Dissimilar Individuals the Same Is Irrational

$\dagger$ Professor of Law, University of South Carolina School of Law. I would like to thank the faculties at the University of South Carolina and the University of North Carolina schools of law for hosting workshops of this article and providing valuable feedback, Thomas Crocker for working through various questions of logic with me, Ned Snow and Benjamin Means for helping me refine certain aspects of the article, and Colin Miller for suggesting substantive additions to the article. Copyright (C) 2015 by Derek W. Black. 
B. Punishing Innocent Individuals Is Irrational. 872

C. Zero Tolerance Disregards Significant Distinctions and Innocence

D. Substantive Due Process and Rational DecisionMaking Require the Consideration of Three Individualized Factors: Intent, Culpability, and Harm

1. Intent

2. Culpability

a. Minors' Diminished Capacity .......................88 889

b. Applying Culpability Analysis to School Discipline.....

c. Culpability Is Lacking with Minor Misbehavior

3. Harm

E. The Presupposition of Key Inquiries Is

Prohibited.....

In the fall of 2013, Erin Cox received a telephone call from an intoxicated friend who was too drunk to drive herself home from a party, so Erin went to get her. ${ }^{1}$ Police officers were there when she arrived and initially detained her. ${ }^{2}$ When they realized why she came and that she had no alcohol in her system, they released her and later submitted an affidavit confirming these facts. ${ }^{3}$ But when school officials learned of the event, they insisted that Erin had violated the school's discipline policy because she had been "in the presence of" alcohol, and took action against her. ${ }^{4} \mathrm{~A}$ few years ago, a school took action against a middle school student, Benjamin Ratner, for coming to the immediate aid of a friend. Benjamin took possession of a suicidal friend's bookbinder that contained a knife, doing so to prevent

1. Doyle Murphy, Massachusetts Honor Student Punished for Driving Drunken Friend Home from Party, N.Y. DAILY NEWS (Oct. 15, 2013), http://www.nydailynews.com/news/national/drunk-logic-sober-teen-suspended -driving-friend-home-party-article-1.1486179.

2. $I d$.

3. Id.

4. Derek Black, School Changing Its Story, EDUC. L. PROF BLOG (Oct. 16, 2013), http://lawprofessors.typepad.com/education_law/2013/10/school -changing-its-story-on-why-it-suspended-student-who-drove-her-drunk-friend -home.html. 
his friend from using it against herself. ${ }^{5}$ For his good deed, the district expelled him for the remainder of the year. ${ }^{6}$ Finally, one middle school expelled a sixth grade boy-whom the school described as a model student-for unknowingly bringing his miniature Swiss army knife to school in his backpack.

Similar stories, more and less serious, abound. Over the last two decades, suspension and expulsion rates in schools have doubled. ${ }^{8}$ The adoption of zero tolerance discipline policies has fueled this rise, not increased student misbehavior. Zero tolerance policies have expanded the categories of behavior for which a student can and must be suspended and expelled. Whether a student's misbehavior is serious, trivial, intentional, or accidental, the response in many districts is the same: exclusion from school. In fact, schools themselves report that minor misbehaviors, like disruption and disrespect, account for ninety-five percent of suspensions and expulsions. ${ }^{9}$ As a result, some schools suspend one out of every two students over the course of each school year. ${ }^{10}$

School districts insist that these suspensions and expulsions are necessary to maintain order and safety. ${ }^{11}$ Students have challenged zero tolerance as a violation of due process, but even in cases as extreme as those above, lower courts consistently conclude that the Constitution provides no meaningful check on these policies. ${ }^{12}$ As the Fourth Circuit wrote in Benja-

5. Ratner v. Loudoun Cnty. Pub. Sch., 16 F. App'x 140, 141 (4th Cir. 2001) (per curiam).

6. Id.

7. Colvin ex rel. Colvin v. Lowndes Cnty. Miss. Sch. Dist., 114 F. Supp. 2d 504, 507-08 (N.D. Miss. 1999).

8. DANIEL J. LOSEN \& RUSSEll SkIBA, S. POVERTy LAW CTR., SUSPENDED EDUCATION: URBAN MIDDLE SCHOOLS IN CRISIS 2 (2010), available at http://www.splcenter.org/sites/default/files/downloads/publication/Suspended_ Education.pdf.

9. DANiEL J. LOSEN \& Tia Elena MARTINeZ, The Civil Rights ProjeCt, OUT OF SCHOOL AND OFF TRACK: THE OVERUSE OF SUSPENSIONS IN AMERICAN MIDDLE AND HIGH SCHOOLS 8 (2013), available at http://civilrightsproject.ucla .edu/resources/projects/center-for-civil-rights-remedies/school-to-prison -folder/federal-reports/out-of-school-and-off-track-the-overuse-of-suspensions -in-american-middle-and-high-schools/OutofSchool-OffTrack_UCLA_4-8.pdf.

10. Eduardo Ferrer, District Discipline: The Overuse of Suspension and Expulsion in the District of Columbia, DC LAW. FOR YOUTH (June 20, 2013), http://dcly.org/district_discipline.

11. See generally JUDITH KAFKA, THE HISTORY OF "ZERO TOLERANCE” IN AMERICAN PUBLIC SCHOOLING 2-3 (2011) (discussing arguments in favor of zero tolerance policies).

12. See generally id. at 107. 
min Ratner's case, "[h]owever harsh the result in this case, the federal courts are not properly called upon to judge the wisdom of a zero tolerance policy." ${ }^{13}$ Lower courts' cursory and dismissive treatment of the constitutional claims raised in these cases is unwarranted, but primarily a result of sparse Supreme Court precedent that leaves lower courts to fill in certain doctrinal gaps on their own. And the gaps are significant.

The concept of zero tolerance in schools was not even on the foreseeable horizon when the Supreme Court first applied procedural due process to student discipline in Goss v. Lopez in 1975. ${ }^{14}$ The Court in Goss announced the general principle that students are entitled to notice of the charges against them and a chance to respond, but left the specifics of the process open. ${ }^{15}$ The only other Supreme Court decision on point came one month later in Wood v. Strickland, ${ }^{16}$ in which the Court held that students could seek monetary damages for due process violations, but that the lower court had erred in failing to defer to the school's construction of its own disciplinary code. With only these sparse guideposts, lower courts' approach to zero tolerance has been of their own making. Rather than substantively engage the constitutional issues implicated by discipline, they have increasingly found that so long as a student receives some rudimentary procedural due process they will not "secondguess" the substance of school rules or their application, even in egregious instances like those mentioned above. ${ }^{17}$

Lower courts have been so consistently emphatic in their position that scholars and advocates have all but conceded the constitutionality of zero tolerance. ${ }^{18}$ Some do no more than call for voluntary policy changes. ${ }^{19}$ Others implicitly assume the

13. Ratner v. Loudoun Cnty. Pub. Sch., 16 F. App'x 140, 142 (4th Cir. 2001) (per curiam).

14. 419 U.S. 565 (1975).

15. $I d$.

16. 420 U.S. 308 (1975). In 1982, the Court did issue a per curiam decision in Board of Education v. McCluskey, 458 U.S. 966 (1982), but the case is rarely cited and holds almost no precedential value as the facts are almost exactly the same as in Wood and the Court simply restates that courts would not disregard a school's reasonable construction of its own rules.

17. Youssef Chouhoud \& Perry A. Zirkel, The Goss Progeny: An Empirical Analysis, 45 SAN DIEGO L. REV. 353, 377-82 (2008).

18. See, e.g., Eric Blumenson \& Eva S. Nilsen, One Strike and You're Out? Constitutional Constraints on Zero Tolerance in Public Education, 81 WASH. U. L.Q. 65, 108 (2003); Aaron Sussman, Learning in Lockdown: School Police, Race, and the Limits of Law, 59 UCLA L. REV. 788, 831-35 (2012).

19. See, e.g., Christina L. Anderson, Double Jeopardy: The Modern Di- 
constitutionality of challenge zero tolerance policies and argue for more robust procedural protections in enforcing them. ${ }^{20}$ Others realize that simply affording more process amounts to doing more of the same. ${ }^{21}$ These scholars rightly look to substantive due process solutions, but propose legal theories that are unsupported by existing precedent and would require courts to rework due process doctrine. ${ }^{22}$ Finally, some ignore due process altogether, believing the only important limitation on discipline is the prohibition on discrimination. ${ }^{23}$

Recognizing the seriousness of the discipline crisis and the lack of legal solutions, on January 8, 2014, the United States Departments of Justice and Education released official policy guidance on the administration of discipline. ${ }^{24}$ The guidance, while an important policy enforcement document, offered nothing new in terms of constitutional analysis or privately enforceable rights. Where positive change has occurred, it has been primarily outside the legal system, coming only recently when large school districts realized their suspensions and expulsions had become an epidemic and that they could not operate func-

lemma for Juvenile Justice, 152 U. PA. L. REV. 1181, 1199-2000 (2004); Miriam Rokeach \& John Denvir, Front-Loading Due Process: A Dignity-Based Approach to School Discipline, 67 OHIO ST. L.J. 277, 300-02 (2006).

20. See, e.g., Emily Bloomenthal, Inadequate Discipline: Challenging Zero Tolerance Policies As Violating State Constitution Education Clauses, 35 N.Y.U. REv. L. \& Soc. Change 303, 326-35 (2011); Amy P. Meek, School Discipline "As Part of the Teaching Process": Alternative and Compensatory Education Required by the State's Interest in Keeping Children in School, 28 YALE L. \& POL'Y REV. 155, 172-83 (2009).

21. See infra note 219 and accompanying text.

22. E.g., Jeffrey D. Jackson, Putting Rationality Back into the Rational Basis Test: Saving Substantive Due Process and Redeeming the Promise of the Ninth Amendment, 45 U. RICH. L. REV. 491, 530-43 (2011); Rosalie Berger Levinson, Reining in Abuses of Executive Power Through Substantive Due Process, 60 FLA. L. REV. 519, 555-59 (2008).

23. See, e.g., Zachary W. Best, Derailing the Schoolhouse-to-Jailhouse Track: Title VI and a New Approach to Disparate Impact Analysis in Public Education, 99 GEO. L.J. 1671, 1672-74 (2011); Russell J. Skiba et al., African American Disproportionality in School Discipline: The Divide Between Best Evidence and Legal Remedy, 54 N.Y.L. SCH. L. REV. 1071, 1086-89 (2010). Some do propose a state law theory that has significant merit but which has been met with mixed reviews in state courts and would be limited to a subset of states. See e.g., Roni R. Reed, Education and the State Constitutions: Alternatives for Suspended and Expelled Students, 81 CORNELL L. REV. 582, 602-21 (1996).

24. U.S. DeP'T OF Justice \& U.S. DeP'T OF Educ., DeAR Colleague LETTER ON THE NONDISCRIMINATORY ADMINISTRATION OF SCHOOL DiscIPLINE (2014), http://www2.ed.gov/about/offices/list/ocr/letters/colleague-201401-title -vi.pdf. 
tional schools without revisiting their zero tolerance policies. ${ }^{25}$

As important as progressive policy developments are-and some are gaining momentum-past experience with contested educational practices suggests that zero tolerance and harsh discipline will remain all too prevalent unless courts intervene to protect students' constitutional rights. ${ }^{26}$ For instance, in 1977 the Court upheld corporal punishment as a permissible means of discipline in schools. ${ }^{27} \mathrm{~A}$ national consensus subsequently turned against the practice, but over thirty years later, corporal punishment continues as a regular occurrence in twenty-one states, resulting in the paddling or "beating" of over two hundred thousand students a year. ${ }^{28}$ There is little reason to expect anything different with zero tolerance, particularly when courts so willingly sanction it. Even if political efforts might end zero tolerance in the future, today's expelled and suspended students are entitled to a reasoned constitutional response now. Suspension and expulsion have never been minor occurrences in students' lives, but today they are the functional equivalent of educational death penalties and second-class citizenship for a whole class of students. ${ }^{29}$

Serious and substantive examination of, rather than perfunctory glances at, zero tolerance and harsh discipline reveals that the Constitution does place meaningful limits on these discipline policies. The recognition of these limits, moreover, is consistent with Supreme Court precedent. This Article argues that fundamental principles of substantive due process call into question zero tolerance and overly harsh discipline. While acknowledging the general permissiveness of the applicable substantive due process test-rational basis-this Article argues that rational basis review requires courts to engage in reasoned and logical analysis of schools' disciplinary goals, including the legitimacy of the goals and the extent to which suspension and

25. See generally Lizette Alvarez, Seeing the Toll, Schools Revise Zero Tolerance, N.Y. TIMES, Dec. 2, 2013, at A1 (discussing a growing national trend among large school districts of moving away from zero tolerance disciplinary policies and towards in-school solutions to student misbehavior).

26. The Supreme Court refused to intervene in corporal punishment in Ingraham v. Wright, 430 U.S. 651 (1977).

27. $I d$.

28. Human Rights Watch, A Violent Education: Corporal PunishMENT OF CHILDREN IN U.S. PUBLIC SCHOOLS 2-3 (2008). Many of these students also suffer from serious long-term emotional, academic, and social effects beyond the corporal punishment itself. Id. at 50-60.

29. See infra notes 50-54 and accompanying text. 
expulsion further those goals. Given the deference owed schools, this basic analysis will, in most instances, favor schools. But this propensity is not an excuse for courts to abdicate the analysis altogether. A commitment to the analysis will reveal that some policies and punishments are so irrational that they cannot be defended.

The most significant contribution of this Article is to go one step beyond the basic doctrine of substantive due process and demonstrate that certain processes, principles, and considerations are so inherent in due process that schools cannot legitimately levy punishment without them, even if doing so might have some administrative benefit for schools. This Article devotes the bulk of its analysis to identifying those inherent principles and applying them to zero tolerance and harsh discipline. The first principle precludes the state from categorizing and punishing significantly dissimilar individuals as though they are the same. ${ }^{30}$ A student with an aspirin in his pocket for a headache is not a drug dealer, and a student who accidentally brings fingernail clippers to school is not a murderer or terrorist. A school may have a rational basis to impose some punishment on those students, but it has no rational basis to expel and treat them as though they are the same as their criminal counterparts. Substantive due process requires that these punished students share some significant and relevant characteristic(s), not just that they share some identifiable characteristic.

The second principle precludes the state from severely punishing "innocent" students, i.e., students who engage in innocuous behavior and/or make good-faith mistakes. ${ }^{31}$ The very purpose of due process is to sort the guilty from the innocent, or in the words of Goss v. Lopez, to determine whether punishment is "warranted." Rules and prohibitions that render this distinction irrelevant violate substantive due process. No amount of hearings and appeals can cure this flaw because the outcome of each hearing and appeal would be premised on an underlying rule that ignores substantive innocence. This is not to say, however, that valid rules never result in the punishment of the innocent. We know this occurs, but we deem those instances to be errors. ${ }^{33}$ These errors are the result of practicalities that prevent the perfect application of substantively valid rules. In

30. See infra notes 263-274 and accompanying text.

31. See infra notes 275-284 and accompanying text.

32. 419 U.S. 565, 579 (1975).

33. See Mathews v. Eldridge, 424 U.S. 319, 344 (1976). 
contrast, a rule that by design punishes the innocent, and insists that doing so is not an error, lacks a legitimate justification. Intentionally punishing innocent individuals is not the result of an inherently imperfect process.

The third principle requires the state to distinguish between dissimilarly situated individuals by giving consideration to, at least, three individualized factors: intent, culpability, and harm. The general rule within our legal system and due process traditions is that, without some level of pertinent intent, the state lacks a legitimate basis upon which to punish an individual's behavior. ${ }^{34}$ There are, of course, exceptions, but they are limited and require specific justification from the state. An individual's culpability and blameworthiness, likewise, bear directly on the legitimacy of the state's interest in imposing punishment. ${ }^{35}$ This is not to suggest that substantive due process requires strict proportionality between punishment and culpability or harm, but it does prohibit a complete disconnect between these factors. The Supreme Court has been most cautious in policing this disconnect when the state imposes ultimate or extreme consequences, and most protective when the subjects of this punishment are children because, as a class, they have diminished mental capacity and culpability. ${ }^{36}$

Finally, due process principles require that these factors, along with any other inquiries relevant to a particular punishment, be considered in the context of the procedures afforded and the evidence presented, not prejudged or predetermined. The law, based on reasoned policy and empirical facts, can presume certain facts to be true, ${ }^{37}$ but it cannot presume facts for which there is no reasoned justification, nor make them effectively irrebuttable. ${ }^{38}$ Doing so eliminates the purpose of afford-

34. See Joseph E. Kennedy, Making the Crime Fit the Punishment, 51 EMORY L.J. 753, 761 (2002).

35. See, e.g., State Farm Mut. Auto. Ins. Co. v. Campbell, 538 U.S. 408, 409 (2003); BMW of N. Am., Inc. v. Gore, 517 U.S. 559, 568, 575 (1996).

36. See Miller v. Alabama, 132 S. Ct. 2455, 2464-66, 2475 (2012) (striking down mandatory life without parole for minors). See generally Roper v. Simmons, 543 U.S. 551, 569-73 (2005) (focusing on minors' reduced culpability and capacity in striking down capital punishment).

37. See, e.g., Keyes v. Sch. Dist. No. 1, Denver, Colo., 413 U.S. 189, 195-97 (1973).

38. See, e.g., Elkins v. Moreno, 435 U.S. 647, 660-61 (1978) (turning on whether the irrebuttable presumption of fact was universally true); Cleveland Bd. of Educ. v. LaFleur, 414 U.S. 632, 644-50 (1974) (same). In the criminal context, the state is prohibited from even "shifting of the burden of persuasion with respect to [an important] fact," much less creating irrebuttable presump- 
ing process and deprives individuals of the individualized consideration of their case to which they are entitled.

Zero tolerance and harsh discipline policies routinely violate all of the foregoing substantive due process principles. Such policies frequently refuse to distinguish between dissimilarly situated individuals-for instance, the drug dealer and the student with an aspirin or, for that matter, the drug dealer and the disrespectful student. The disregard for distinctions between students is so extreme that many zero tolerance policies would expel an otherwise innocent student, such as a student who may have had a prohibited item in his backpack or car, but did not know it was there. ${ }^{39}$ Given this callousness, it is no surprise that zero tolerance and harsh discipline preclude the consideration of core due process inquiries: a student's intent, culpability, or harm to the educational environment. Moreover, they preclude these factors in the context of imposing the most extreme punishment-banishment from school permanently or the remainder of the year-the very context in which substantive due process demands that the state be most attentive to these considerations. Even when these inquiries are not entirely precluded, they are prejudged with irrebuttable presumptions that reduce many disciplinary hearings to charades that go through the motions of process, but do not deliberate its substantive inquiries. Thus, contrary to the general assumption of lower courts, many aspects of zero tolerance and harsh discipline are unconstitutional.

These overreaches of school authority have grown so gross that intervention by the Supreme Court is increasingly plausible. Although on different constitutional grounds, the Court in recent years has been willing to strike down overly-invasive strip searches of students and coercive custodial interrogations on school grounds. ${ }^{40}$ This Article provides the constitutional analysis by which the Court can do the same in zero tolerance without altering existing precedent.

This Article proceeds in four Parts. Part I further explains the extent of the suspension and expulsion crisis in schools, explores whether its cause is school policy or student misbehavior, and articulates the goals that schools seek to promote with their policies. Part II analyzes the role and rationale of courts

tions. Patterson v. New York, 432 U.S. 197, 210, 215 (1977).

39. See, e.g., Seal v. Morgan, 229 F.3d 567, 571-72 (6th Cir. 2000).

40. J.D.B. v. North Carolina, 131 S. Ct. 2394 (2011); Safford Unified Sch. Dist. v. Redding, 557 U.S. 364 (2009). 
in school discipline, tracing the Supreme Court's initial intervention in the early 1970 s to the lower courts' disengagement today. In particular, it identifies the goals and limits of Goss $v$. Lopez and lower courts' flawed interpretation of Wood v. Strickland. Part III explains and applies the substantive due process theory by which to limit zero tolerance and overly harsh discipline. The Article concludes with a brief, forward-looking discussion of the efficacy of pursuing this doctrine.

\section{THE CURRENT CRISIS IN DISCIPLINE}

\section{A. THE Rise AND BREADTH OF EXPULSIONS AND SUSPENSIONS}

School discipline has entered a new era in terms of its breadth and seriousness. In the years leading up to the Court's decision in Goss v. Lopez, ${ }^{41}$ the annual suspension rate for all racial groups, except African Americans, was below ten percent. ${ }^{42}$ The total number of annual suspensions was about one and a half million. ${ }^{43}$ Since then, the number of suspensions has doubled and the rate for each demographic group has increased significantly. ${ }^{44}$ Today, the suspension rate for African Americans in middle and high school is a staggering twenty-four percent and above ten percent for every other major demographic group except Asians. ${ }^{45}$ The numbers are even worse for some subpopulations. ${ }^{46}$ These problems have also crept into elementary schools, where suspension and expulsion previously almost never occurred, but are now routine. ${ }^{47}$ These national numbers mask an outright crisis in many individual districts and schools. In the 2009-10 academic year, over five hundred schools in the country suspended more than half of their stu-

41. 419 U.S. 565 (1975).

42. LOSEN \& MARTINEZ, supra note 9, at 1 fig.1 (showing that in 1972-73 the suspension rates among black students was $11.8 \%$, among Latino students was $6.1 \%$, among White students was 6\%, among American Indian students was 5.6\%, and among Asian and Pacific Island students was 2.4\%, and showing that the suspension rates in 2009-10 for each group was $24.3 \%, 12 \%, 8.4 \%$, $7.1 \%$, and $2.3 \%$, respectively).

43. Rokeach \& Denvir, supra note 19, at 282.

44. Id.

45. LOSEN \& MARTINEZ, supra note 9 , at 1 . $19.3 \%)$

46. Id. at 3 (showing that disabled students are suspended at a rate of

47. Judith A. Browne, AdVANCEMENT Project, DERAIled: The SCHOOLHOUSE TO JAILHOUSE TRACK 11 (2003). 
dents. ${ }^{48}$ Some middle schools in the District of Columbia Public Schools have twice as many suspensions as they do students. ${ }^{49}$

The significance of suspension and expulsion has also grown to the point where they are more appropriately understood as de facto educational death penalties than as corrective or management tools. ${ }^{50} \mathrm{~A}$ suspension is not a one-time event for many students. Roughly forty percent of the student suspensions in any given school year are multiple suspensions. ${ }^{51}$ In Texas, students who were suspended or expelled just once during middle or high school were subsequently suspended or expelled, on median, three more times. ${ }^{52}$ These suspended students are not intrinsically predisposed to repeated misbehavior. Rather, longitudinal studies show that suspension reinforces a student's poor behavior and/or the subjective perception that the child is a troublemaker. ${ }^{53}$ Thus, suspension becomes a predictor, rather than a deterrent, of later suspension and discipline problems. ${ }^{54}$

A single suspension, similarly, places students at high risk of long-term expulsion, drop-out, unemployment, and ultimately prison. ${ }^{55}$ Studies reveal that suspension and expulsion are

48. LOSEN \& MARTINEZ, supra note 9 , at 3 .

49. Ferrer, supra note 10.

50. Mark Yudof used the term "Academic Capital Punishment" as early as 1975, Mark G. Yudof, Suspension and Expulsion of Black Students from the Public Schools: Academic Capital Punishment and the Constitution, 39 LAW \& CONTEMP. PROBS. 374, 374 (1975), but his use was more hyperbolic than analytical. He did not actually use the term in the text of his article.

51. See MASS. AdVOCACY CTR., ThE WAY OUT: STUdENT EXClusion PRACTICES IN Boston Middle SCHOOLS 53 (1986) (studying Boston middle school students); see also Christine Bowditch, Getting Rid of Troublemakers: High School Disciplinary Procedures and the Production of Dropouts, 40 Soc. PROBS. 493, 498-99 (1993) (showing that 35.2\% of students suspended were suspended for repeated school violations); Virginia Costenbader \& Samia Markson, School Suspension: A Study with Secondary School Students, 36 J. SCH. PSYCHOL. 59, 70-71 (1998) (showing that 37\% of students suspended at least once believed that they would be suspended again in the future).

52. TONY FABElO ET AL., BREAKING Schools' RUles: A Statewide STUdy of How School Discipline Relates to STUDENTS' SuCCESS AND JUVENILE JUSTICE INVOLVEMENT 37-38 (2011), available at http://issuu.com/csgjustice/docs/breaking_schools_rules_report_final-1/1?e= $2448066 / 1603396$.

53. Linda M. Raffaele Mendez, Predictors of Suspension and Negative School Outcomes: A Longitudinal Investigation, 99 NEW DIRECTIONS FOR YouTH DEV. 17, 25, 28-29 (2003); Tary Tobin et al., Patterns in Middle School Discipline Records, 4 J. EMOTIONAL \& BEHAV. DISORDERS 82, 91 (1996).

54. Tobin et al., supra note 53, at 91 .

55. Id. 
one of the most significant factors in a student's decision to drop out of school, ${ }^{56}$ and, for many students, dropping out may not be entirely voluntary. Under pressure to improve standardized test scores in recent decades, some schools have used suspension and expulsion as a way to rid themselves of undesirable low-performing students. ${ }^{57}$ Regardless of the cause, fifty percent of students who drop out of school become unemployed. ${ }^{58}$ A significant percentage of drop outs, for predictable reasons, are subsequently incarcerated. ${ }^{59}$ The path from suspension to prison is not happenstance. Various studies document how the school discipline system has become a pipeline into the prison system, increasing students' risk of contact with the criminal justice system and directly referring students to the juvenile justice system. ${ }^{60}$

In other words, suspension and expulsion are not temporary withdrawals of education services that scare students straight. Rather, as the Fifth Circuit wrote of expulsion in 1974:

[A] sentence of banishment from the local educational system is, insofar as the institution has power to act, the extreme penalty, the ultimate punishment. In our increasingly technological society getting at least a high school education is almost necessary for survival. Stripping a child of access to educational opportunity is a life sentence to second-rate citizenship. ... ${ }^{61}$

56. See, e.g., id.

57. Michelle Fine, Why Urban Adolescents Drop Into and Out of Public High School, 87 TCHRS. C. REC. 393, 403-04 (1986); Davin Rosborough, Left Behind, and Then Pushed Out: Charting a Jurisprudential Framework To Remedy Illegal Student Exclusions, 87 WASH. U. L. REV. 663, 665-66 (2010).

58. Rokeach \& Denvir, supra note 19 , at 286.

59. See generally id. ("[A]s much as $80 \%$ of the prison population is composed of high school dropouts.").

60. See, e.g., AdVAnCEMEnt Project, Test, Punish, and Push-Out: How “ZERO TOLERANCE” AND High STAKES TESTING FunNEL YOUTH INTO THE SCHOOL-TO-PRISON PIPELINE 3, 18-19 (2010), http://b.3cdn.net/advancement/ d05cb2181a4545db07_r2im6caqe.pdf; FLA. DEP'T OF JUVENILE JUSTICE, DELINQUENCY IN FLORIDA'S SCHOOLS: A FOUR YEAR STUDY 5-6, 17-18 (2009), available at http://www.djj.state.fl.us/docs/research2/2007-2008_delinquency school_analysis.pdf; Katayoon Majd, Students of the Mass Incarceration Nation, 54 How. L.J. 343, 347-48 (2011); Reed, supra note 23, at 606; Terence P. Thornberry et al., The Effect of Dropping Out of High School on Subsequent Criminal Behavior, 23 CRIMINOLOGY 3, 7 (1985); see also Gary Sweeten, Who Will Graduate? Disruption of High School Education by Arrest and Court Involvement, 23 JUST. Q. 462, 471-75 (2006) (analyzing the effect of juvenile delinquency referral on a student's graduation).

61. Lee v. Macon Cnty. Bd. of Educ., 490 F.2d 458, 460 (5th Cir. 1974). 
Today students' prospects are worse. The entry qualifications to higher education and meaningful work are sufficiently high, the interaction between schools and the criminal justice system so tight, and the risk factors so well documented, that suspensions and expulsions are the functional equivalent of permanently ending many students' educational careers and condemning them to jail. While this connection is not an absolute, it is likely and serious.

\section{B. The CAUSAl EXPLANATION FOR INCREASED EXPULSION AND SUSPENSION}

One might assume that increased student misbehavior is the cause of increased suspension and expulsion rates, but the data does not bear that notion out. ${ }^{62}$ Data indicates that students are not misbehaving any more today than they were in prior eras. ${ }^{63}$ With regard to the most serious misbehaviorviolence-today's students, according to the data, are slightly better behaved. ${ }^{64}$ Even were this not the case, violence at school is but a small percentage of students' misbehavior. ${ }^{65}$ Thus, an increase in serious misbehavior cannot substantiate the increase in discipline in recent decades. The increases are just too stark.

Instead, the increase in suspensions and expulsions is primarily a function of two phenomena: suspending students for a broader array of behavior and adopting zero tolerance policies toward that behavior. Today's schools suspend students for behavior that they historically ignored or addressed through counseling and minor punishment. Until the last two decades, expulsion and suspension were largely reserved for major infractions. ${ }^{66}$ Today, schools suspend and expel students for al-

62. See Blumenson \& Nilsen, supra note 18 , at 71 ; Majd, supra note 60 , at 364-65.

63. See Blumenson \& Nilsen, supra note 18, at 71; Majd, supra note 60 , at 364-65.

64. AdVANCEMENT PROJECT, supra note 60, at 10; see also Majd, supra note 60 , at 367 .

65. Jill F. DeVoe ET AL., U.S. DeP'T OF Educ. \& U.S. DeP’T OF JUSTICE, INDICATORS OF SCHOOL CRIME AND SAFETY: 2004, at 6-13 (2004), http://nces.ed.gov/pubs2005/2005002.pdf; LLOYD D. JOHNSTON ET AL., INST. FOR SOC. RESEARCH, UNIV. OF MICH., MONITORING THE FUTURE: QUESTIONNAIRE RESPONSES FROM THE NATION'S High SCHOOL SENIORS 113 (2005), http://monitoringthefuture.org/datavolumes/2005/2005dv.pdf.

66. See Blumenson \& Nilsen, supra note 18, at 71; cf. Brent E. Troyan, Note, The Silent Treatment: Perpetual In-School Suspensions and the Educa- 
most anything: truancy, cheating, running in the hall, dress code violations, foul language, and disrespect. ${ }^{67}$ Just recently, a high school student in Indiana was expelled for the school year for his juvenile attempt at creative language use on the internet-inserting the "f-word" multiple times in a single sentence-even though he did not direct his language toward anyone and it was done in the middle of the night from home. ${ }^{68}$

Suspension and expulsion under like circumstances are not the acts of rogue administrators. Rather, various state statutes have turned minor misbehaviors into grounds for suspension and expulsion. ${ }^{69}$ As a result, ninety-five percent of suspensions today are for what schools themselves characterize as "disruptive" or "willful" behavior. ${ }^{70}$ Some schools and states are willing to suspend or expel students based on one instance of minor misbehavior, ${ }^{71}$ whereas others rely on something akin to a "three strikes and you're out" approach to minor misbehavior. ${ }^{72}$

tion Rights of Students, 81 TEX. L. REV. 1637, 1641-42 (2003) (stating that expulsion and suspension sanctions are not reserved for major infractions).

67. See, e.g., CAL. EDUC. CODE $\$ 48900$ (West 2014) (including "[c] ommitted an obscene act or engaged in habitual profanity or vulgarity" and "[d]isrupted school activities or otherwise willfully defied the valid authority of supervisors, teachers, administrators, school officials, or other school personnel engaged in the performance of their duties" as expellable offenses); Sandra Tan, In Buffalo, NY, Students No Longer Suspended for Minor Misbehavior, BREAKING SCHOOL-TO-PRISON PIPELINE (Apr. 24, 2013), http://www .breakingthepipeline.org/2013/04/25/in-buffalo-students-no-longer-suspended -for-minor-misbehavior.

68. Austin Carroll, Indiana High School Student, Expelled for Tweeting Profanity, HuFFington POST (Mar. 25, 2012, 1:32 PM), http://www .huffingtonpost.com/2012/03/25/austin-carroll-indiana-hi_n_1378250.html.

69. See, e.g., MISS. CODE ANN. § 37-11-18.1 (2014); S.C. CODE ANN. § 5963-210 (2014); see also Joy Resmovits, School Discipline Changes Urged in Federal Complaint Against Dallas Truancy System, Huffington Post (June 6, 2013, 12:00 AM), http://www.huffingtonpost.com/2013/06/12/school -discipline-changes-dallas-truancy_n_3423820.html (reporting that three absences in four weeks is a class $\mathrm{C}$ misdemeanor in Texas).

70. Arne Duncan, U.S. Sec'y of Educ., U.S. Dep't of Educ., Rethinking School Discipline (Jan. 8, 2014), available at http://www.ed.gov/news/speeches/ rethinking-school-discipline; Jolon McNeil, Zero Tolerance, Zero Opportunity, JUV. JUST. PROJECT OF LA., http://jjpl.org/zero-tolerance-zero-opportunity (last visited Dec. 18, 2014); cf. LOSEN \& MARTINEZ, supra note 9 , at 8 (discussing the increase in the use of suspensions at every level of education).

71. Blumenson \& Nilsen, supra note 18, at 71-72.

72. See, e.g., MISS. CoDE ANN. § 37-11-18.1 (2014) (stating that three instances of classroom "disruption" is a basis for expulsion); S.C. CODE ANN. $\S 59-63-210$ (establishing persistent disruption as a basis to expel); Blumenson $\&$ Nilsen, supra note 18, at 71; Rokeach \& Denvir, supra note 19, at 280-82. 
Statutes and school district policies have also restricted the discretion of administrators in determining whether suspension and expulsion are warranted. ${ }^{73}$ Suspension and expulsion are now mandatory in many instances. ${ }^{74}$ This mandatory approach, or "zero tolerance," is almost uniform in regard to serious behavior. Ninety-one percent of schools have adopted zero tolerance toward weapons, and just short of ninety percent have adopted zero tolerance toward drugs and alcohol. ${ }^{75}$ Those percentages may seem reasonable if by 'weapon' one means a gun, or by 'drugs' one means marijuana. But schools have given those terms expansive meaning, ensnaring students who either do not pose a danger to anyone or have not engaged in behavior that an objective observer would perceive as a violation of the schools' policies. Consider the suspension or expulsion of the middle school student who brought an over-the-counter medicine to school to treat an illness, the six year old who ate his lunch with his beloved cub scout tool, and the girl whose first aid kit in her car contained a small knife. ${ }^{76}$ Even if safety demanded zero tolerance for the possession of more serious items, the rationale would not follow for minor behavior, which accounts for the overwhelming percentage of suspensions and expulsions.

\section{The Rationale and EFFeCtiveness of Zero Tolerance AND HARSH DISCIPLINE}

The motivations and theories behind the zero tolerance and harsh discipline policies are complex. An individual state, district, or school can hold multiple different theories and motivations. $^{77}$ This makes speaking of zero tolerance in monolithic terms problematic. But on the whole, a few major motivations are at play to varying degrees, depending on the locale or administrator. Blumenson and Nilsen identify three major goals

73. See Blumenson \& Nilsen, supra note 18 , at 71-72.

74. Id. at $69-72$.

75. CATHERINE Y. Kim et AL., The SChoOl-TO-PRISON PIPELINE: STRUCTURING LEGAL REFORM 79 (2010) (stating that 87\% of schools have zero tolerance for alcohol and $88 \%$ have zero tolerance for drugs, and that $79 \%$ of schools adopt zero tolerance toward violence).

76. See, e.g., John J. Garman \& Ray Walker, The Zero-Tolerance Discipline Plan and Due Process: Elements of a Model Resolving Conflicts Between Discipline and Fairness, 1 FAULKNER L. REV. 289, 308-09 (2010); J. Kevin Jenkins \& John Dayton, Students, Weapons, and Due Process: An Analysis of Zero Tolerance Policies in Public Schools, 171 EDUC. L. REP. 13, 14-15 (2003).

77. See, e.g., ADVANCEMENT PROJECT, supra note 60, at 11-12, 14, 25-26. 
of zero tolerance: deterring misbehavior, incapacitating disruptive and dangerous students, and ensuring consistent responses to misbehavior, with an aim toward reducing racial disparities. $^{78}$

Each of these goals is presumptively legitimate. To be effective, schools must minimize disruptive behavior and maintain safety. Without an ordered and safe environment, neither the misbehaving nor behaving students will fully benefit from the substantive curriculum. If misbehaving students are susceptible to deterrence, some form of negative consequence is one way of achieving order. Finally, consistent and unambiguous responses to misbehavior can further equitable discipline both within and between demographic groups. Zero tolerance, however, has not achieved any of these ends. This alone, of course, does not render zero tolerance unconstitutional under prevailing standards, but the efficacy of zero tolerance is important background for this Article's subsequent constitutional analysis.

Data indicates that harsh discipline and zero tolerance have resulted in the exclusion of more students without actually deterring or improving student behavior. ${ }^{79}$ If zero tolerance were an effective deterrent, one would expect suspensions and expulsions to fall rather than rise. Instead, nuanced analysis indicates that overly harsh discipline simply begets more discipline, rather than deterring the behavior that leads to it. ${ }^{80}$ Excluding a student makes it more likely that the student will be excluded again, ${ }^{81}$ but overly harsh discipline also negatively affects the overall school environment. Students who attend schools with higher rates of suspension and expulsion perceive their environment to be less safe and more chaotic. ${ }^{82}$ This perception is an outgrowth not of higher rates of violence and mis-

78. Blumenson \& Nilsen, supra note 18 , at 75-87.

79. See, e.g., ADVANCEMENT PROJECT, supra note 60, at 14-15, 17.

80. See, e.g., Bowditch, supra note 51, at 498-99; Costenbader \& Markson, supra note 51 , at 71 .

81. See Bowditch, supra note 51, at 498-99; Costenbader \& Markson, supra note 51, at 71 .

82. See James Earl Davis \& Will J. Jordan, The Effects of School Context, Structure, and Experiences on African-American Males in Middle and High Schools, 63 J. NEGRO EDUC. 570, 585 (1994); Russell J. Skiba \& M. Karega Rausch, Zero Tolerance, Suspension, and Expulsion: Questions of Equity and Effectiveness, in HANDBOOK OF ClASSROOM MANAGEMENT: RESEARCH, PRACTICE, AND CONTEMPORARY ISSUES 1063, 1072 (Carolyn M. Evertson \& Carol S. Weinstein eds., 2006), available at http://www.indiana.edu/ equity/docs/Zero_ Tolerance_Effectiveness.pdf. 
behavior, but of the harsh response to that behavior. Among otherwise similarly situated schools, those with more punitive and rigid discipline approaches have the worst educational environments $^{83}$ and lowered academic achievement. ${ }^{84}$ In other words, the ultimate goal of order-learning and achievementis undermined. As Richard Arum's study reveals, while students can and do respect discipline and order, they perceive it as random and unfair when it becomes too strict. $^{85}$ At that point, students become distrustful of authority, and many rebel against the perceived unfairness. ${ }^{86}$

Those committed to zero tolerance might counter that, even if harsh discipline does not deter misbehavior, it serves the important goal of incapacitating students when they misbehave. This point, however, is of limited assistance in defending zero tolerance on the whole. First, incapacitation as a legitimate goal relates to dangerous or seriously disruptive students. Disruptive students do not warrant or need incapacitation; they need behavioral improvement. At some point, student misbehavior is sufficiently trivial that a school could not claim that incapacitating the student serves any rational purpose. Without defining precisely where that line is, it suffices to say that only a small portion of school exclusions are in response to danger or serious disruption. ${ }^{87}$ Moreover, as to lowlevel disruptions, studies show that after a school excludes one disruptive student another student will tend to take his place or, at least, a student will be perceived as having done so, ${ }^{88}$ par-

83. M. Karega Rausch \& Russell J. Skiba, The Academic Cost of Discipline: The Relationship Between Suspension/Expulsion and School Achievement 24-25 (Apr. 2005) (paper presented at the American Educational Research Association Conference, Montreal, Canada) (on file with author), available at http://www.indiana.edu/ atlantic/wp-content/uploads/2014/03/ Academic-Cost-of-School-Discipline.pdf.

84. Linda M. Raffaele Mendez et al., School Demographic Variables and Out-of-School Suspension Rates: A Quantitative and Qualitative Analysis of a Large, Ethnically Diverse School District, 39 PsYCHOL. ScHS. 259, 270-71 (2002).

85. RIChard ARUM, JUdging School Discipline: The CRISIS OF MoRAL AUTHORITY 34 (2003).

86. See id.; see also Paul M. Bogos, "Expelled. No Excuses. No Exceptions."-Michigan's Zero Tolerance Policy in Response to School Violence: M.C.L.A. Section 380.1311, 74 U. DET. MERCY L. REV. 357, 381 (1997) (stating that zero tolerance "and similar measures-often harden delinquent behavior patterns, alienate troubled youths from the schools, and foster distrust" (internal quotation mark omitted)).

87. See Skiba \& Rausch, supra note 82, at 1069-70.

88. Cf. Blumenson \& Nilsen, supra note 18, at 81 (stating that the statis- 
ticularly in a school with a negative climate. Taken to its extreme, using incapacitation to address minor disruptions could lead a school to exclude students until there are almost none left to teach, a result plainly inconsistent with a school's constitutional and statutory duty to deliver public education. In short, incapacitation may be a legitimate disciplinary goal, but it only justifies a small slice of school exclusion. The rest of school exclusions must rely on some other justification.

The remaining justification for zero tolerance-eliminating inconsistent and biased application of discipline-falls short as well. Rather than shrink the gap in exclusion rates between minorities and whites, zero tolerance has expanded it. ${ }^{89}$ Minorities tend to be disproportionately referred to the "office" for punishment for subjective misbehavior, like noise, disruption, and disrespect; whites tend to be disproportionately referred for objective behavior, like smoking, leaving without permission, and vandalism. ${ }^{90}$ Prior to zero tolerance, most schools already took a harsh approach to these objective misbehaviors. ${ }^{91}$ The variation existed in the response to more subjective and less serious behaviors. ${ }^{92}$ Thus, the practical effect of zero tolerance in many schools was to increase the punishment for those behaviors for which minorities were disproportionately cited.

The flaw is that zero tolerance focuses on the wrong level of the decision-making process. It ignores classroom bias and the differential response to student misbehavior, which are the primary sources of racial disparities in discipline, not the principal's office. ${ }^{93}$ All zero tolerance has done is to ensure that the-

tics do not significantly show that removing troublesome students from the classroom reduces disruptions or enhances safety).

89. See e.g., KIM ET AL., supra note 75, at 2 (stating that, for example, black students are three times more likely to be suspended than white students).

90. Russell J. Skiba et al., The Color of Discipline: Sources of Racial and Gender Disproportionality in School Punishment, 34 URBAN REV. 317, 332 (2002), available at http://www.indiana.edu/ equity/docs/ColorofDiscipline 2002.pdf.

91. See KAFKA, supra note 11 , at $17,46$.

92. $C f$. AdVAncement Project, A Real Fix: The Gun-Free Way to SCHOOL SAFETY 16 (2013), available at http://b.3cdn.net/advancement/ 2739bdc85740f69645_pwm6bck09.pdf (discussing some of the types of subjective infractions zero tolerance policies may punish); ADVANCEMENT PROJECT, supra note 60 , at $13-14$ (same). 317.

93. LOSEN \& MARTINEZ, supra note 9, at 2; Skiba et al., supra note 90, at 
se biased referrals to the principals are followed by harsh discipline.

\section{THE COURTS' GRAND CONSTITUTIONAL INTERVENTION AND SILENT WITHDRAWAL FROM SCHOOL DISCIPLINE}

\section{A. The GoAls of GoSS V. LOPEZ}

The Supreme Court's first major intervention in school discipline was in 1975 in Goss v. Lopez. ${ }^{94}$ In Goss, the Court held that due process protections apply to the suspension and expulsion of students. ${ }^{95}$ Before a school can deprive a student of his right to education, it must afford the student notice of the basis upon which he is to be punished and an opportunity to respond. ${ }^{96}$ Today, this holding appears so obvious and unobtrusive that Goss appears mundane in retrospect. At the time, however, education was confronting a crisis, of which discipline was a part, and the particular outcome in Goss was not preordained.

Many today forget that Goss was decided within a much larger context than just discipline. The decision came on the heels of an expansive period of school desegregation and rapidly developing law. ${ }^{97}$ As African Americans and whites came into greater contact, tensions developed. In many districts, the outlet for that tension was discipline policy, through which biased actors indirectly resisted desegregation and acted upon bias. ${ }^{98}$ Immediately following Goss, J. Harvie Wilkinson wrote, "Goss ultimately represents more of a sequel to Brown v. Board of Education than to the free speech cases. If in Brown the racial

94. 419 U.S. 565 (1975)

95. Id. at $582-83$.

96. Id. at 581 .

97. See generally Gary ORFIELD \& Chungmei LeE, The Civil Rights PROJECT, BROWN AT 50: King's DREAM OR PLESSY'S NIGHTMARE? (2004) (detailing the rapid rise of school integration during the 1970s). School integration did not begin in earnest until Congress passed the Civil Rights Act of 1964 and the Court subsequently articulated the details of desegregation. See, e.g., Milliken v. Bradley, 433 U.S. 267 (1977); Keyes v. Sch. Dist. No. 1, Denver, Colo., 413 U.S. 189 (1973); Swann v. Charlotte-Mecklenburg Bd. of Educ., 402 U.S. 1 (1971); Green v. Cnty. Sch. Bd., 391 U.S. 430 (1968).

98. S. ReG'L Council \& Robert F. Kennedy Mem'L, The Student Pushout: ViCTIM OF CONTINUED RESISTANCE TO DESEGREGATION, at ix (1973); U.S. COMM'N ON CIVIL RIGHTS, FULFILLING THE LETTER AND SPIRIT OF THE LAW: DESEGREGATION OF THE NATION'S PUBLIC SCHOOLS 47-50 (1976) [hereinafter FULFILLING THE LETTER]. 
question was very much on the surface, in Goss it lay not very far below." The underlying purpose of Goss was to "vindicate the promise of Brown ... . [and, through hearings,] help relieve racial tensions by enhancing the appearance of evenhanded discipline." 100

The five Justices in the Goss majority perceived their decision as delivering a monumental victory for discipline reform; ${ }^{101}$ the four dissenters characterized it as a monumental mistake. ${ }^{102}$ The disagreement centered on competing theories of education and discipline, rather than the process itself. In Brown-like fashion, the Goss majority focused on justifying intervention in discipline, which it did through educational goals and theories, and offered only a vague and minimal explanation of the particular process it was justifying. ${ }^{103}$ The first step for the majority was simply to identify a constitutional basis upon which to intervene. The majority held that Ohio's compulsory education statute vested students with a property right in education that triggered due process. ${ }^{104}$

At the time, this analytic step was enormous. The Court's other two most significant education rights decisions-Brown $v$. Board of Education ${ }^{105}$ and San Antonio v. Rodriguez ${ }^{106}$-had treated education as a contingent right. Brown had emphasized the importance of education ${ }^{107}$ but refrained from declaring it a fundamental or vested property right. ${ }^{108}$ The Court in Rodriguez explicitly held that education was not a fundamental right. ${ }^{109}$ The Goss dissenters, likewise, would have emphasized that education was not a fundamental right and that the state was free to make the statutory right conditional. ${ }^{110}$ Thus, the

99. J. Harvie Wilkinson III, Goss v. Lopez: The Supreme Court As School Superintendent, 1975 SUP. CT. REV. 25, 30 (1975).

100. Id. at 32 .

101. Goss v. Lopez, 419 U.S. 565, 583-84 (1975).

102. Id. at 585-86 (Powell, J., dissenting).

103. Id. at 580, 582 (majority opinion).

104. Id. at 576 .

105. 347 U.S. 483 (1954).

106. 411 U.S. 1 (1973).

107. Brown, 347 U.S. at 493.

108. Id. (indicating that equal protection applies to education only when "the state has undertaken to provide it").

109. Rodriguez, 411 U.S. at 37.

110. Goss v. Lopez, 419 U.S. 565, 587 (1975) (Powell, J., dissenting) ("The Court ... disregards the basic structure of Ohio law in posturing this case as if Ohio had conferred an unqualified right to education, thereby compelling the 
majority's recognition of a vested right in education and the protections of due process marked a new doctrinal era for education and discipline.

Beyond the predicate questions of whether an education right exists and due process applies, the majority itself was conflicted, with the practicalities and pedagogy of education weighing heavily on its analysis. The Court's concern with fair discipline results required some level of process to avoid "erroneous" outcomes, but the Court emphasized that discipline is about more than just punishing students for substantiated misbehavior. ${ }^{111}$ The majority and the dissent agreed that discipline is a pedagogical tool whereby schools teach students good behavior, good citizenship, consequences, and personal responsibility. ${ }^{112}$ The Court assumed that schools' motivation for discipline is largely benevolent, rather than punitive, and designed to serve the interests of the disciplined student. ${ }^{113}$ Thus, the Court was cautious about requiring procedures that would, as it saw it, undermine the educational function of discipline and transform it into an overly adversative process. ${ }^{114}$

school authorities to conform to due process procedures in imposing the most routine discipline.").

111. Id. at 580-84 (majority opinion).

112. Id. at 580 ("Some modicum of discipline and order is essential if the educational function is to be performed. Events calling for discipline are frequent occurrences and sometimes require immediate, effective action. Suspension is considered not only to be a necessary tool to maintain order but a valuable educational device."); id. at 592 (Powell, J., dissenting) ("Education in any meaningful sense includes the inculcation of an understanding in each pupil of the necessity of rules and obedience thereto. This understanding is no less important than learning to read and write. One who does not comprehend the meaning and necessity of discipline is handicapped not merely in his education but throughout his subsequent life. In an age when the home and church play a diminishing role in shaping the character and value judgments of the young, a heavier responsibility falls upon the schools .... The lesson of discipline is not merely a matter of the student's self-interest in the shaping of his own character and personality; it provides an early understanding of the relevance to the social compact of respect for the rights of others. The classroom is the laboratory in which this lesson of life is best learned. Mr. Justice Black summed it up: 'School discipline, like parental discipline, is an integral and important part of training our children to be good citizens-to be better citizens." (quoting Tinker v. Des Moines Indep. Cmty. Sch. Dist., 393 U.S. 503, 524 (1969) (Black, J., dissenting))).

113. See id. at 580 (majority opinion).

114. Id. at 583 (" $[\mathrm{F}]$ ormalizing the suspension process and escalating its formality and adversary nature may not only make it too costly as a regular disciplinary tool but also destroy its effectiveness as part of the teaching process."). 
Both the majority and dissent conceptualized discipline as pedagogical and benevolent, but parted ways on the weight to afford this conceptualization. The majority did not believe this was a basis upon which to entirely exempt discipline from due process procedures, ${ }^{115}$ whereas the dissent argued that requiring any type of procedure would undermine the pedagogy of discipline. ${ }^{116}$ The majority, however, was sufficiently sympathetic toward the dissent's position that it articulated due process requirements in vague broad terms, ${ }^{117}$ which allowed schools to retain flexibility in administering discipline. Regardless of which side was correct, this internal debate reveals that the imposition of discipline in Goss was about far more than the process itself. Goss was premised on a set of judicial and educational goals-protecting students' rights, accuracy in results, pedagogically effective discipline, and non-adversarial discipline.

\section{B. THE FLAWS OF GOSS V. LOPEZ}

The Court's opinion in Goss has fallen far short of its goals. The flaw in Goss is not that it intervened in discipline, but that its intervention was too weak. The Court relied on assumptions that later proved false and failed to articulate due process standards that were rigorous enough to stand the test of practicality. The Court was likely aware of the latter point and may very well have intended to issue more forceful subsequent opinions, rolling out progressive doctrine over time. But solutions in subsequent opinions never came. If the Court never intended a subsequent opinion, the Goss dissenters have been proven correct, insofar as the majority's half-measure solution for discipline may be worse than no solution at all. ${ }^{118}$ Regardless, the doctrine that Goss did announce remains in effect and demands the further development that never occurred.

The following subsections focus on three major flaws in Goss. The first section reveals the Court's assumption that those administering discipline would necessarily act with benevolence toward students and in the disciplined students' best interests. The second section analyzes the particular due process standard that the Court adopted in Goss, critiquing its lack of substantive limits on school officials who do not act be-

115. Id. at $579-80$.

116. Id. at 585 (Powell, J., dissenting).

117. Id. at 583-84 (majority opinion).

118. See id. at 597-99 (Powell, J., dissenting). 
nevolently or thoughtfully toward students. The third section discusses the inability of the Court to evolve and cure the vague doctrine in Goss due to changes in the Court's composition, which the majority in Goss should have foreseen.

\section{The Assumption of the "Benevolent Administrator"}

The first flaw in Goss was the Court's assumption that the non-adversarial theory of education would persist naturally, notwithstanding the Court's intervention. The Court wrote, "[W]e do not believe that we have imposed procedures on school disciplinarians which are inappropriate in a classroom setting. Instead we have imposed requirements which are, if anything, less than a fair-minded school principal would impose upon himself in order to avoid unfair suspensions." ${ }^{119}$ Thus, the Court expected that administrators would implement and apply due process with good faith and benevolence.

The Court may have wanted to have its cake and eat it too on this score. The notion that most schools would interpret Goss as practically inconsequential is inconsistent with the Court's notion that Goss was monumental. Even if Goss imposed only a minimal burden, the perception from the classroom and principal's office was far different. ${ }^{120}$ The burdenwhatever its weight-fell solely on teachers and administrators, and they would henceforth be accountable in court for carrying it. ${ }^{121}$ Being naturally benevolent, which the Court assumed on the part of schools, is far different than being held accountable for benevolence by the legal system. This reality colored schools' perception of what might have otherwise been a minimal burden. ${ }^{122}$

Subsequent data suggests that Goss's mandate incited school-level resistance to thoughtful and robust procedures, and incentivized process for the sake of process. ${ }^{123}$ Today, school officials and teachers perceive the disciplinary process as ad-

119. Id. at 583 (majority opinion)

120. ARUM, supra note 85, at 30 .

121. Id.

122. Id.; see also Chouhoud \& Zirkel, supra note 17, at 353 ("Last year, upon the thirtieth anniversary of the Supreme Court's decision in Goss v. Lopez, the then-general counsel of the National School Boards Association decried the expansion of Goss from a 'three minute give and take' to the 'paralysis' of public school discipline.").

123. ARUM, supra note 85, at 30 . 
versarial, ${ }^{124}$ which alters their entire approach. Thirty years after Goss, the general counsel of the National School Boards Association concluded that due process had "create[d] a paralysis" in schools and teachers, ${ }^{125}$ who now "fumbl[e] away through their daily disciplinary dealings with students wondering and working at their peril." ${ }^{126}$ School personnel indicate that they believe Goss constrains their discretion, imposes unnecessary procedural and operational burdens, ${ }^{127}$ and places them at odds with students. ${ }^{128}$ Both process and the students have become the enemy. ${ }^{129}$ Schools' response has been to routinize process to produce the favored result. ${ }^{130}$ Rather than a deliberative or collaborative process aimed at accuracy, justice, or educational lessons, due process is the routine through which a school must run. ${ }^{131}$

Richard Arum argues that, by granting students legal recourse for deprivations of process, Goss placed students and schools in adversarial positions and undermined the moral authority of schools, the latter of which he cites as a primary evil of Goss. ${ }^{132}$ An equally plausible explanation is that school officials overreacted to Goss and failed to appreciate the significant discretion Goss reserved for them. Thus, the Court is not entirely to blame. Regardless, the practical result is the same: the disciplinary process is no longer the educational tool the Court imagined. Schools now focus on documenting process rather

124. Id.; cf. Jessica Falk, Overcoming a Lawyer's Dogma: Examining Due Process for the "Disruptive Student," 36 U. MICH. J.L. REFORM 457, 468 (2003) (discussing how students perceive traditional due process hearings as adversarial, with school personnel against them).

125. Julie Underwood, The 30th Anniversary of Goss v. Lopez, 198 EDUC. L. REP. 795, 802 (2005).

126. Id. at 803 .

127. Chouhoud \& Zirkel, supra note 17, at 357 \& n.23.

128. See Betsy Levin, Educating Youth for Citizenship: The Conflict Between Authority and Individual Rights in the Public School, 95 YALE L.J. 1647, 1672 (1986) (stating that the legalization of dispute resolution in the schools potentially sets students and teachers up as adversaries rather than as participants in the learning process).

129. See ARUM, supra note 85, at 30 (stating that by the late 1970 s, fiftynine percent of teachers indicated that court decisions had hampered schools). See generally Falk, supra note 124, at 468 (discussing the adversarial nature of traditional due process hearings); Levin, supra note 128, at 1672 (same).

130. See generally KAFKA, supra note 11, at 6 (discussing the bureaucratization and centralization of discipline in response to Goss).

131. ARUM, supra note 85, at 5.

132. Id. at 4 . 
than affording meaningful process, thereby undermining the pedagogical use of discipline.

\section{Indefinite and Substanceless Standards}

The Court's concern with burdening the assumed "fairminded" administrator led to a second major flaw: a decision devoid of meaningfully enforceable substance. To protect both students' rights and the educational value of discipline, the Court in Goss needed to do more than announce grand theories and principles. ${ }^{133}$ Beyond the basic idea of affording notice and response, Goss is a relatively hollow decision that ignored key issues and left others obviously open. ${ }^{134}$ The Court in Goss conceptualized due process in discipline as an investigation into whether discipline is warranted, with the goal being to reach the correct result. ${ }^{135}$ If by "warranted" or "correct," the Court meant that a student has engaged in prohibited behavior, the broad dictates of Goss are theoretically sufficient to achieve that end. The Court's language in Goss - "determin[ing] whether the misconduct has occurred" 136 -is certainly susceptible to this narrow meaning.

Determining that an individual has engaged in some particular act, however, does not automatically answer the question of whether a particular punishment is normatively or constitutionally warranted. The latter question also requires a substantive evaluation of a student's behavior and the range of available punishments. ${ }^{137}$ The Court in Goss makes no mention of a student's culpability as an inquiry of due process, nor does it indicate that a school might need to justify some punishments, particularly harsh ones, with a meaningful, important, or substantial justification. The lack of specificity on this point is not per se problematic. The Court's "fair-minded" administrator would consider a student's culpability and the necessity of discipline. But where the fair-minded administrator is not

133. Josie Foehrenbach Brown, Developmental Due Process: Waging a Constitutional Campaign To Align School Discipline with Developmental Knowledge, 82 TEMP. L. REV. 929, 959 (2009); Wilkinson, supra note 99, at 73.

134. EllEN JANE HOLLINGSWORTH ET AL., SCHOOL DISCIPLINE: ORDER AND AUTONOMY 127 (1984); Brown, supra note 133, at 957; Wilkinson, supra note 99 , at $29-30$.

135. Brown, supra note 133 , at 994.

136. Goss v. Lopez, 419 U.S. 565, 574 (1975).

137. See generally Jane Rutherford, The Myth of Due Process, 72 B.U. L. REV. 1, 4-5 (1992). 
involved, procedural consideration of these points is essential, as it is the only thing left to protect the student.

Even the "fair-minded" administrator is not immune from the problem, particularly when process has been routinized and offered primarily for the sake of process. If culpability and necessity are not part of the routinized consideration, they can easily go unaddressed. Thus, whether the administrator is malevolent or benevolent, the Court's failure to articulate a substantive limitation on school discipline seriously risks the possibility that the Court's broad goals and principles will ring completely hollow where they are needed most. ${ }^{138}$ At best, the issues of culpability and appropriate discipline are left open by Goss. At worst, they are irrelevant because the only objective of the process is to assess whether a particular behavior occurred. ${ }^{139}$ The latter would leave schools free to turn discipline codes into strict liability codes, in which intent and culpability are irrelevant.

The Court's distinction between long- and short-term suspensions, however, did hint at some underlying substantive limits. With the most severe penalties, the Court indicated schools should be more careful. ${ }^{140}$ "Longer suspensions or expulsions for the remainder of the school term, or permanently, may require more formal procedures." ${ }^{141}$ But the Court did not explore what more formal procedures might look like or a standard by which to gauge them. In this respect, the Court was not per se committed to any formal procedures, ${ }^{142}$ which leaves the opinion dangerously insufficient from the perspective of students. Once long-term punishment is at issue, the assumption of benevolence by an administrator almost necessarily vanishes. The school's purpose is to exclude a perceived threat or problem (i.e., the student), not to use discipline as a teaching tool. ${ }^{143}$ Thus, while the notion of heightened process

138. Brown v. Bd. of Educ., 374 U.S. 483, 495 (1954).

139. See Goss, 419 U.S. at 574.

140. Id. at 584 .

141. Id.

142. Lower courts treat eleven days as a per se trigger. See, e.g., Doe ex rel. Doe v. Todd Cnty. Sch. Dist., 625 F.3d 459, 462 (8th Cir. 2010).

143. See Brooke Grona, School Discipline: What Process Is Due? What Process Is Deserved?, 27 AM. J. CRIM. L. 233, 233 (2000) ("Perhaps it is as disciplinarian that the school most delicately balances its roles: as state, as quasiparent, as police, and as educator. But in its goal to achieve safety on the campus, the school loses its concern for educating the student."); Levin, supra note 128, at 1672 . 
for longer suspensions might hint at substantive limits, the Court's opinion is not even sufficient to protect procedural rights, much less substantive ones.

3. Goss as the First Step in an Unfolding Judicial Project That Never Came To Be

That the Court would announce important constitutional doctrine, leave it intentionally vague, and never refine it is problematic. The Court was either naively optimistic about what Goss would achieve or intended it to be but the first in a series of progressively evolving discipline decisions. ${ }^{144}$ A progressive approach would have had pragmatic value. The Court in Brown v. Board of Education, for instance, took this approach, initially saying nothing as to the meaning of desegregation, nor when and how schools would achieve it. ${ }^{145}$ Moving too far too fast might have overstretched the Court's institutional capacities, undermining both effective desegregation and the Court's authority. ${ }^{146}$ Thus, the Court waited over a decade to issue the decisions that offered the substantive specifics of desegregation. ${ }^{147}$ The contentiousness of disciplinary due process pales in comparison to desegregation, but a similar approach in Goss would have made sense given that the Court was reforming a major aspect of education that was intertwined with school culture and bias.

That approach, by necessity, would have required subsequent action by the Court. Without later decisions like Green $v$. County School Board of New Kent ${ }^{148}$ to impose affirmative duties and identify specific criteria to measure compliance, Brown would have had very little effect on the education of students. In fact, during the decade between Brown and Green, actual desegregation was non-existent. Less than two percent of children in the South attended desegregated schools. ${ }^{149}$ The same principle applies to Goss. The broad concept of due process im-

144. See generally Wilkinson, supra note 99 (discussing the issues with and limitations of the Goss decision, as perceived in 1975).

145. DEREK W. Black, EdUCATION LAW: EQUALITy, FAIRNESS, AND REFORM 29 (2013).

146. See generally ALEXANDER M. BICKEL, THE LEAST DANGEROUS BRANCH: The Supreme CourT AT THE BAR OF Politics (2d ed. Yale Univ. Press, 1986).

147. See, e.g., Swann v. Charlotte-Mecklenberg Bd. of Educ., 402 U.S. 1

(1971); Green v. Cnty. Sch. Bd., 391 U.S. 430 (1968).

148. 391 U.S. 430 (1971).

149. FULFILLING THE LETTER, supra note 98 , at 6 . 
bedded in Goss risked irrelevance unless it was followed by a hypothetical Doe v. School District. ${ }^{150}$ Doe never came because the Court either naively thought benevolent administrators eliminated the need or misjudged the times, assuming that those supporting liberal school ideology would remain the majority on the Court. ${ }^{151}$ Regardless, in retrospect, Goss is seriously flawed in its lack of detailed and contextualized due process standards. ${ }^{152}$

The lack of specificity in Goss left its broad principles subject to retraction. The basic holding of Goss - that due process applies to educational deprivations and requires notice and an opportunity to respond-has never been questioned, but tangentially related cases have undermined and curtailed its impact. In fact, the four Goss dissenters later became the controlling majority in cases that practically and ideologically vindicated their Goss dissent. ${ }^{153}$ Just one month after Goss, the Court decided Wood v. Strickland. ${ }^{154}$ The primary issue was whether school board members were immune from damages for due process violations. ${ }^{155}$ The majority held that school board members who knew or should have known they were violating due process were subject to damages. ${ }^{156}$ The same four Justices who had dissented in Goss dissented again in Wood, rejecting that holding and questioning the normative educational goals the majority was espousing. ${ }^{157}$ Justice Powell, the author of both the Goss and Wood dissents, ${ }^{158}$ objected to any judicial in-

150. See generally Brown, supra note 133, at 930-31 (discussing the Court's failure to follow Goss with subsequent reinforcing decisions).

151. I say "naively" because, at the time of Goss, the Court had already decided deeply divided new cases placing limits on school desegregation. See, e.g., Milliken v. Bradley, 418 U.S. 717 (1974) (five opinions); Keyes v. Sch. Dist. No. 1, Denver, Colo., 413 U.S. 189 (1973) (five opinions, with Justice White abstaining).

152. Even if the Court did not flesh out every detail of due process, any details would have made a John Doe case less necessary and, equally important, would have guarded the case against the indirect retraction that followed.

153. See e.g., Ingraham v. Wright, 430 U.S. 651, 652 (1977).

154. 420 U.S. 308 (1975).

155. Id. at 314 .

156. Id. at 322 .

157. Id. at 327-31 (Powell, J., dissenting); Goss v. Lopez, 419 U.S. 565, 584

(1975) (Powell, J., dissenting).

158. Wood, 420 U.S. at 327 (Powell, J., dissenting); Goss, 419 U.S. at 584 (Powell, J., dissenting). 
tervention that might alter the delivery of discipline,${ }^{159}$ remarking that "[i]n view of today's decision significantly enhancing the possibility of personal liability, one must wonder whether qualified persons will continue in the desired numbers to volunteer for service in public education."

The Court in Wood also addressed whether, as a factual matter, a due process violation had occurred. ${ }^{161}$ In Wood, a school regulation prohibited the use or possession of intoxicating beverages. ${ }^{162}$ No question arose as to whether the school had followed proper procedures in punishing the students. Rather, the question was whether the school could define "intoxicating beverage" itself or was bound by the state's statutory definition of "intoxicating liquor," which mattered because the students' beverage did not meet the statutory definition. ${ }^{163}$ The court of appeals applied the statutory definition and reversed the punishment. The Supreme Court reinstated the punishment, finding that the record established that the school had adopted its own definition and had the authority to do so. ${ }^{164}$

On these points, Wood is rather unremarkable. The case simply held that school officials, like other state officials, are subject to suit, but endowed with discretion in adopting and administering their own regulatory code. What was striking was the Court's hostility to the lower court's review of the case. ${ }^{165}$ The Court wrote:

It is not the role of the federal courts to set aside decisions of school administrators which the court may view as lacking a basis in wisdom or compassion. Public high school students do have substantive and procedural rights while at school. But $\S 1983$ does not extend the right to relitigate in federal court evidentiary questions arising in school disciplinary proceedings or the proper construction of school regulations. ... [P] ublic education ... relies necessarily upon the discretion and judgment of school administrators and school board members, and $\$ 1983$ was not intended to be a vehicle for federalcourt corrections of errors in the exercise of that discretion which do

159. Wood, 420 U.S. at 331 (Powell, J., dissenting) (arguing that the majority's good faith immunity analysis imposed a higher standard on school officials).

160. Id.

161. Id. at 327 (majority opinion).

162. Id. at 310 .

163. Id. at $324-26$.

164. Id.

165. The lower court opinion also vacillated between a procedural and substantive due process review, but the Court interpreted it as based on substantive due process. Id. at 326-27. 
not rise to the level of violations of specific constitutional guarantees. ${ }^{166}$

The tone of this quote is hard to reconcile with the holding in Goss, particularly since the two cases were decided a month apart. One explanation is that, contrary to this Article's analysis, Goss was intended as a minimalist decision, not to reform discipline or offer meaningful protections. The hostile quote in Wood would support that notion. It is also consistent with the weak and flexible nature of Goss's due process mandate and with the Court's failure to strengthen it later. This explanation, however, does not explain the actual holding in Goss and its historical significance. Wilkinson's exploration of the overall historical record compellingly demonstrates that the Court in Goss was responding to underlying evidence of racially disparate practices and intentionally breaking important new doctrinal ground. ${ }^{167}$ Wading into this contested area just to offer an advisory opinion-one that was not internally defended against subsequent retraction by the harsh dissent-would have been a fool's errand that stood the chance of doing more harm than good. More important, Goss extends new rights to students and Wood makes them enforceable with monetary damages. ${ }^{168}$ Regardless of their practical flaws, these holdings represent concrete doctrinal expansion. Read this way, Wood does not vindicate a minimalist Goss, but is still part of a measured and progressive roll out of Goss. For this reason, it drew the same vigorous dissenters from Goss.

The rebuke of judicial review in Wood, nonetheless, did occur and requires further explanation. The rebuke likely had more to do with the facts of Wood than anything else. The students had admittedly brought alcohol to school, consumed it, given it to unsuspecting third parties, and then sought to escape liability on the technicality that the alcohol level was too low to be classified as an alcoholic beverage under state law. ${ }^{169}$ That the court of appeals would reverse punishment in this context troubled the entire Court, which unanimously rejected the lower court's reinterpretation of the school's code. ${ }^{170}$ While the majority in Goss intended due process to serve educational goals and prevent unwarranted discipline, the Court in Wood

166. Id. at 326 (citations omitted).

167. Wilkinson, supra note 99, at 31-32.

168. Wood, 420 U.S. at 322.

169. Id. at $325-26$.

170. Id. at 324-25. 
makes clear that it did not intend due process to serve as the mechanism whereby courts would permit misbehaving students to escape punishment or to seek de novo reviews of evidence and school rules. ${ }^{171}$ In fact, intervention in this context would be inconsistent with the Court's theory of the benevolent administrator acting in students' best interests. Intervention would have also been a move toward an inherently adversarial and legalized disciplinary process, in which courts stood on the side of students seeking to out-argue well-intentioned school officials.

While Wood can be synthesized with Goss, Ingraham v. Wright $t^{172}$ - a corporal punishment case in 1977-cannot. Ingraham marked a real shift on the Court toward the Goss and Wood dissenters. The Court in Ingraham held that schools need not afford students any process prior to imposing corporal punishment. $^{173}$ The Court found the available post-punishment remedies under state law sufficient to protect students' rights. ${ }^{174}$ Because Ingraham involved corporal punishment and Goss involved suspension, Ingraham did not overrule Goss, but the cases are logically inconsistent. A one-day suspension is sufficient to trigger due process and require advance notice and an opportunity to respond under Goss, ${ }^{175}$ whereas the deprivation of physical liberty in Ingraham does not. The Court's rationale in Ingraham is straightforward and mirrors the dissent in Goss: a pre-punishment process is burdensome and undermines the educational effectiveness of corporal punishment. ${ }^{176}$ The Court ignored the logical inconsistency with Goss, summarily distinguishing it as a case about property. ${ }^{177}$ The cases, however, are inseparable because both raise the same exact questions of educational pedagogy and disciplinary procedures. In these respects, Ingraham marks a post facto limitation on Goss's doctrine and rationale.

In 1985 in New Jersey v. T.L.O. ${ }^{178}$ the Court again undermined the rationale of Goss. Because T.L.O. was a Fourth

171. Id. at 326 .

172. 430 U.S. 651 (1977).

173. Id. at 682 .

174. Id.

175. Goss v. Lopez, 430 U.S. 565, 575-76 (1974).

176. Ingraham, 430 U.S. at 680; Goss, 430 U.S. at 585-86 (Powell, J., dissenting).

177. Ingraham, 430 U.S. at 674 n.43; Wood, 420 U.S. at 310.

178. 469 U.S. 325 (1985). 
Amendment search case, ${ }^{179}$ its specific doctrine is only tangentially related to Goss. But as a practical matter, searches are necessarily connected to due process and punishment because searches uncover the contraband leading to discipline. Likewise, the ideological connection to Goss is strong because T.L.O. poses the same issue of administrative flexibility in regulating student behavior. The Court in T.L.O., however, cast aside the idealism of Goss, making clear that any progressive agenda that Goss might have contemplated was foreclosed. Instead, T.L.O. reinforced the Ingraham approach.

First, the Court in T.L.O. exempted schools from the generally applicable probable cause standard, ${ }^{180}$ without, according to the dissent, offering any doctrinally defensible justification. ${ }^{181}$ In place of probable cause, the Court adopted the far more permissive and malleable "reasonable suspicion" test for school searches. ${ }^{182}$ Second, and more problematic for disciplinary pedagogy and doctrine, the Court in T.L.O. treated violations of all school rules as equivalent in terms of their ability to justify a search. ${ }^{183}$ In other words, whether the suspicion is of writing a dirty note or possessing cocaine, both offer an equally compelling justification for a search. The Court in Goss, in contrast, had clearly distinguished between long- and short-term punishments and, by implication, certain types of behavior. Each warranted a different due process response. ${ }^{184}$ T.L.O. left that due process principle untouched, but gave schools free reign in the investigation that precedes the process. Minor misbehavior could subject students to the same level of privacy invasion as criminal behavior. ${ }^{185}$ Thus, T.L.O., unlike Goss, is not premised as a meaningful check on discipline, but a validation of nearly unfettered investigatory authority by schools.

In sum, the line of cases necessary to reinforce and evolve Goss never came. The precedential vacuum was filled by a line of related cases that revisited Goss's underlying premises. Although the cases left Goss's holding intact, they cabined and circumscribed Goss's impact. As a result, Goss's final legacy fell short of its initial promise. First, students may be due some

179. Id. at 327 .

180. Id. at 341 .

181. Id. at 354 (Brennan, J., dissenting).

182. Id. at 341 (majority opinion).

183. Id. at $341-42$.

184. Goss v. Lopez, 419 U.S. 565, 576 (1974).

185. See T.L.O., 469 U.S. at 342. 
process before suspension, but process is vague and not susceptible to strict enforcement. Second, the process does not apply to discipline across the board, even punishment as severe as "beating." Third, schools are entitled to extensive deference in terms of the behavioral rules they set and how they investigate them. These three principles prevent courts from interfering with the proper functioning of schools, but they also impede the protection of rights that Goss indicated students have.

\section{REDUCING Disciplinary HEARINGS to A SHAM}

The internal flaws of Goss and the subsequent cabining of its doctrine have resulted in due process practices that, as a practical matter, are often reduced to a sham. Even without the benefit of hindsight, Wilkinson predicted this would occur. ${ }^{186} \mathrm{He}$ wrote that the "skeletal" and "threadbare" process guaranteed by Goss is "anything but searching" 187 and "hardly . . . sufficient to protect . . . against deprivation by pretext."188 Absent the benevolent administrator, due process would not be "an exercise in democracy, but more a charade which authorities play as quickly as possible in order to reach the predetermined res[u]lt." ${ }^{189}$ David Kirp joined Wilkinson, concluding that, in absence of substantive protections, Goss hearings could be reduced to "prepunishment ceremonies." "190

Donald Stone's empirical study of schools' due process hearings two decades later confirms these warnings. His study revealed wild variations in terms of what procedures schools followed in suspension hearings, if a hearing was even held at all. ${ }^{191}$ First, an in-person hearing before the board or hearing officer only occurred fifty-three percent of the time. ${ }^{192}$ In urban districts, only forty-one percent of students received an inperson hearing. ${ }^{193}$ While most districts reserved the official decision to suspend for the school board or a hearing officer, boards and school officers saw their role not as adjudicating a deliberative process in which a student could participate, but as

186. Wilkinson, supra note 99 , at $40-42$.

187. Id. at 40,42 .

188. Id. at 30 .

189. Id. at 72 .

190. David L. Kirp, Proceduralism and Bureaucracy: Due Process in the School Setting, 28 STAN. L. REV. 841, 842 (1976).

191. Donald H. Stone, Crime \& Punishment in Public Schools: An Empirical Study of Disciplinary Proceedings, 17 AM. J. TRIAL ADVOC. 351, 359 (1993).

192. Id.

193. Id. 
acting upon the recommendation of its inferior officer, the principal. ${ }^{194}$ Second, even when districts afforded students a hearing, they frequently failed to afford students basic notice protections or to place the burden of substantiating the charges on the state. ${ }^{195}$ The absence of deliberative hearings and basic protections within them is counter to the "fair-minded" assessment Goss expected, and more akin to the charades feared by Wilkinson and Kirp. It is no surprise then that Stone found that students were suspended eighty-five percent of the time. ${ }^{196}$

The sham-like nature of process has become so normative that courts may not recognize it, even when it is called to their attention. The Sixth Circuit's opinion in Newsome v. Batavia ${ }^{197}$ offers a prime example. Arthur Newsome was accused of possessing and selling marijuana at his high school. ${ }^{198}$ The only evidence presented against him was the principal's recitation of two anonymous students' accusations. ${ }^{199}$ Newsome denied the allegations and even passed a drug test, but was nonetheless expelled. ${ }^{200}$ Newsome claimed that the district had deprived him of sufficient process, including the right to cross-examine, to have his attorney represent him, and to have an impartial decision-maker. ${ }^{201}$ The court rejected those claims, ${ }^{202}$ but did grant him relief on a single point. Through court-ordered discovery, Newsome learned that "the superintendent disclosed to the school board, during their closed deliberations, new evidence which had not been presented during the open hearing." ${ }^{203}$ The court held that this violated his due process right to notice. $^{204}$

This narrow victory, however, overlooked the flaw permeating the entire process: a single-minded intent to expel New-

194. See id. at 367 (finding that the disciplinary hearing ended in suspension in eighty-five percent of the cases in which the school recommended that the student be suspended).

195. Id. at 355,364 (indicating that $65 \%$ of students did not receive a summary of the evidence, and $30 \%$ of hearings only required preponderance of the evidence, while $52 \%$ required clear and convincing evidence as the standard and $18 \%$ used reasonable doubt as the standard).

196. Id. at 367 .

197. 842 F.2d 920 (6th Cir. 1988).

198. Id. at 921 .

199. Id. at $921-22$.

200. Id. at 921 .

201. Id. at 922 .

202. Id. at $924-27$.

203. Id. at 927 .

204. Id. 
some, regardless of process. Had Newsome never sued the school board and survived dispositive motions, he would never have known that the school board was having ex parte conversations with the principal and gathering secret evidence. The court in Newsome is, of course, correct that the school's actions deprived him of notice, but lack of notice was emblematic of an inherently flawed and biased process. Recognizing this, Newsome's claim focused more heavily on the denial of an impartial decision-maker, the absence of which infected the entire process.

Newsome emphasized that his principal had been involved in the investigation, initial recommendation, and closed door discussions with the school board. ${ }^{205}$ The court responded that the multi-stage involvement of a single administrator does not raise due process concerns. ${ }^{206}$ According to the court, Newsome failed to make the crucial showing: "that the principal and/or superintendent possessed either a pre-existing animus towards him, or had developed a bias because of their involvement in the incident." ${ }^{207}$ This response belies common sense and the facts of the case. The principal gathered information against Newsome, withheld some of that information, and then used it to privately influence the final decision-maker. Newsome was deprived of due process not simply because he lacked notice, but because the entire school apparatus was arrayed against him. It is hard to imagine that notice would have had any effect on the outcome in Newsome's hearing because the hearing did not include serious or fair deliberation. That the board was willing to conduct its deliberations and make its real decisions behind a cloak reveals that the open and formal process required by Goss was a charade. Without insisting on procedures that would limit and ferret out ex parte deliberations and partiality, a finding that Newsome's notice rights were violated does nothing to protect other students. Even if students sense their process is a charade, they will have no basis to know their notice rights, or other substantive rights, have been violated.

While Newsome is egregious, it is not anomalous. Other courts would have rejected Newsome's impartiality claim for the same reasons. ${ }^{208}$ Courts also tend to be similarly dismissive

205. Id. at 926 .

206. Id. at $926-27$.

207. Id. at 927 n.5.

208. See generally BLACK, supra note 145, at 554-66 (reviewing Newsome and other courts' treatment of due process in school discipline). 
of other pleas for procedural protections, even when their absence raises normative questions about whether a disciplinary hearing was meaningful or fair. ${ }^{209}$ States and school districts occasionally implement more rigorous procedural protections voluntarily, particularly in regard to expulsions. ${ }^{210}$ But where schools do not act voluntarily, federal courts are generally unwilling to impose any additional process. ${ }^{211}$ Thus, the flexible approach articulated by Goss, in which process would vary based upon circumstances, has come to operate in a single direction: one that affords minimal process. ${ }^{212}$ Moreover, Stone's data and cases like Newsome indicate that Goss's minimalistic articulation of due process rights is insufficient to ensure meaningful participation or operate as a serious check on suspension and expulsion decisions.

In The Myth of Due Process, June Rutherford explains that there are two overriding goals of due process: meaningful participation in the decision-making process by the individual and a substantive limitation on the state's exercise of power against the individual. ${ }^{213}$ Simply affording some form of process does not necessarily accomplish these goals. In Rutherford's words, "the King at least must consider the [subject's] views" and doing so requires process that affords the subject meaningful participation. ${ }^{214}$ Even when the "King" affords the subject an opportunity to participate:

209. See Thomas R. Baker, Construing the Scope of Student Conduct Codes: Recent Federal Rulings Suggest Heightened Court Scrutiny Ahead, 174 EDUC. L. REP. 555, 575-77 (2003).

210. Perry A. Zirkel \& Mark N. Covelle, State Laws for Student Suspension Procedures: The Other Progeny of Goss v. Lopez, 46 SAN DIEGO L. REv. 343, 350-52 (2009). Some state supreme courts and courts of appeal have applied more pressure on due process because school finance precedent had classified education as a fundamental or constitutional right, which would require more rigorous process. See, e.g., State ex rel. G.S., 749 A.2d 902, 906-08 (N.J. Super. Ct. Ch. Div. 2000); King ex rel. Harvey-Barrow v. Beaufort Cnty. Bd. of Educ., 704 S.E.2d 259, 260-61 (N.C. 2010); Phillip Leon M. v. Greenbrier, 484 S.E.2d 909, 911 (W. Va. 1996); In re RM, 102 P.3d 868, 872-77 (Wyo. 2004). But see Doe v. Superintendent of Sch., 653 N.E.2d 1088, 1095-98 (Mass. 1995).

211. See BLACK, supra note 145 , at 562-66.

212. As a general proposition, one might defend a minimalist approach as consistent with Goss, but insofar as Goss offered flexibility in relationship to circumstances, a minimalist approach is inconsistent with changes in educational circumstances following Goss. As discussed earlier, the consequences of suspension and expulsion are far more serious today, and the right at stake is a fundamental or constitutional one under state law. See supra notes 50-60 and accompanying text.

213. Rutherford, supra note 137, at 5 .

214. Id. at 6-7. 
[I]f the governing principle is too vague, the opportunity to participate may be meaningless. For example, King John could have adopted a rule that all who displeased him would be fined 200 chickens. Such a rule, however, would be too vague because those affected might not understand what displeased him. The mere right to a hearing would not solve the problem because the King alone would retain the power to determine what displeased him. Hence, part of the purpose of procedural due process is to act as a mechanism to assure that the substantive legal principle is adequate. ${ }^{215}$

Offering minimal or inadequate process, ironically, works to the advantage of the state, rather than the individual, because it affords the state a chimera of legitimacy and fairness. The very existence of process, regardless of its minimalist quality, can "validate an otherwise inadequate governing principle." ${ }^{216}$ Without process that both affords meaningful participation and operates as a substantive check on the validity of the principle by which the individual is judged, "those in power are free to be arbitrary." ${ }^{217}$ Because neither Goss nor any subsequent discipline case articulates a basis upon which to evaluate the reasonableness of a school's justification for punishment, Goss leaves schools free to act arbitrarily. Rather than a deliberative or collaborative process, due process has become the routine through which a school must run to achieve a predetermined result. ${ }^{218}$ So long as they do this, schools' disciplinary decisions are imbued with validity, and courts find they have complied with the Constitution.

\section{Substantive Due Process: A Claim Never Fully CONSIDERED}

When process becomes pointless or sham-like in nature, the solution is not necessarily more process because the problem is equally substantive. As Jane Rutherford explains, "the procedural and substantive components of many decisions are inextricably linked." ${ }^{219}$ Recognizing as much, litigants subjected to less than meaningful or fair process have sought to raise substantive due process claims in addition to, or in place of, procedural due process claims. Substantive due process, in theory, is the safety valve for irrational disciplinarians and those

215. Id. at 7 .

216. Id.

217. Id.

218. See generally KAFKA, supra note 11, at 7 (discussing the bureaucratization and centralization of discipline in response to Goss).

219. Rutherford, supra note 137, at 7. 
who lack a sufficient justification for punishing or excluding students. This strategy, however, has proved just as ineffective as, if not more than, procedural due process claims.

The problem, like most others in school discipline, stems from the fact that Goss did not directly address substantive due process. The only other relevant Supreme Court precedent is Wood v. Strickland, which included the problematic warning that "[i]t is not the role of the federal courts to set aside decisions of school administrators which the court may view as lacking a basis in wisdom or compassion." ${ }^{220}$ While Goss explicitly extends procedural due process-which inherently requires some level of rationality-and Wood extends liability for its violation, lower courts have more often disregarded these basic holdings and interpreted Wood as foreclosing substantive due process review. So long as a school followed some sort of process, courts have upheld discipline, no matter how severe or illogical.

The Fourth Circuit's opinion in Ratner v. Loudoun County Public Schools ${ }^{221}$ may demonstrate the worst example: a court refusing to scrutinize expulsion even when both the court and the school admit that a student poses no threat to the educational environment. ${ }^{222}$ Ratner, a middle school student, was

220. Wood v. Strickland, 420 U.S. 308, 326 (1975).

221. 16 F. App'x 140, 142 (4th Cir. 2001) (per curiam).

222. See also Dunn v. Fairfield Cmty. High Sch. Dist. No. 225, 158 F.3d 962, 965-66 (7th Cir. 1998) (offering two sentences of substantive due process review). In Dunn v. Fairfield, two high school students played an unauthorized guitar piece (a solo) in band class, for which the school removed the students from the class for the remainder of the year and barred them from basketball games. Under the class grading policy, the students also received "F"s as final grades, which prevented one of the students from graduating with honors. Id. at 963-64. While one could make a plausible argument that punishment was too harsh in relation to the behavior, the stronger argument attacks the logic and fairness of punishing students academically for behavioral misconduct. The students did not cheat, fail to demonstrate academic competency, or anything of the sort, which would normally be the case for academic punishment. Instead, they acted out behaviorally. Had it been treated as behavioral, the worst-but far from certain punishment-one could imagine would have been short-term suspensions, which, ironically, would likely have had a lesser effect on the students' academic records. The court, however, did not even humor their claims, characterizing them as trivial in comparison to other substantive due process deprivations. $I d$. at 965-66. Its entire analysis amounted to the statement that discipline does not violate substantive due process "unless it is wholly arbitrary," and here the students "freely conceded that they had violated a school rule, that the rule was designed to preserve discipline in the classroom and to punish student insubordination, and that these were legitimate interests on the part of the school district." Id. at 966. 
friends with a girl who had attempted suicide on previous occasions and, on the day in question, "told Ratner that she had been suicidal the previous evening and had contemplated killing herself by slitting her wrists. She also told Ratner that she inadvertently had brought a knife to school in her binder that morning." ${ }^{223}$ To protect her, Ratner took her binder from her and placed it in his locker. ${ }^{224}$ Shortly thereafter, the school's dean became aware of the events and summoned Ratner to her office, where Ratner turned over the knife. ${ }^{225}$ The dean indicated that "Ratner acted in what he saw as the girl's best interest and that at no time did Ratner pose a threat to harm anyone with the knife," but the assistant principal, nonetheless, suspended Ratner for ten days. ${ }^{226}$ Four days later, the superintendent increased the punishment to an indefinite suspension, after which the school board increased the punishment to expulsion for the remainder of the school year.

Ratner filed suit alleging due process, equal protection, and Eighth Amendment violations. The lower court dismissed for failure to state a claim, and the Fourth Circuit affirmed, writing:

The district court also concluded, correctly, that the school officials gave Ratner constitutionally sufficient, even if imperfect, process in the various notices and hearings it accorded him, and we agree.

However harsh the result in this case, the federal courts are not properly called upon to judge the wisdom of a zero tolerance policy of the sort alleged to be in place at Blue Ridge Middle School or of its application to Ratner. Instead, our inquiry here is limited to whether Ratner's complaint alleges sufficient facts which if proved would show that the implementation of the school's policy in this case failed to comport with the United States Constitution. We conclude that the facts alleged in this case do not so demonstrate. ${ }^{228}$

These four sentences are the entirety of the court's evaluation of Ratner's claim. The court jumps to a conclusion without any serious reasoning. This jump is premised on two simple but incorrect premises: (1) the provision of process, rather than its sufficiency, is determinative for purposes of procedural due process; and (2) substantive due process review is beyond the scope of permissible judicial review because it requires courts

Thus, the court forewent any further scrutiny of the discipline.

223. Ratner, 16 F. App'x at 141.

224. Id.

225. Id.

226. Id.

227. Id. at $141-42$.

228. Id. at 142 (citation omitted). 
to assess the rationality of discipline policy. These premises, if correct, would render meaningless the procedural and substantive due process rights that Goss and Wood indicate students hold.

Clearly troubled by the result in Ratner, Judge Hamilton wrote a concurrence that suggested the rationale on which to dig deeper. ${ }^{229}$ But Hamilton, ironically, believed the court was without authority to do so. Hamilton wrote:

[T] he question raised by the facts of Ratner's case is one of degree and the law must be flexible enough so that school officials may intrude upon the right to a free appropriate public education only in the most justifiable circumstances. Under a facts/circumstances-sensitive examination of this case, Ratner's nearly four-month suspension from middle school is not justifiable. Indeed, it is a calculated overkill when the punishment is considered in light of Ratner's good-faith intentions and his, at best, if at all, technical violation of the school's policy. Suffice it to say that the degree of Ratner's violation of school policy does not correlate with the degree of his punishment. Certainly, the oft repeated maxim, "there is no justice without mercy" has been defiled by the results obtained here. But alas, as the opinion for the court explains, this is not a federal constitutional problem. ${ }^{230}$

This quote expresses Hamilton's intuitive sense that the school ought to be constrained in expelling harmless and/or innocent students, but he did not take the next step of engaging in the legal analysis that might substantiate his sense or confirm the constitutionality of the school's action. Rather, he, like the majority, assumed the school's action was beyond constitutional reproach.

No doubt, the Supreme Court in Wood strongly disapproved of the lower court's substantive due process review, but reading the Court's opinion to foreclose substantive due process review altogether is an over-interpretation. First, as discussed earlier, the Court's opinion in Wood primarily focused on qualified immunity. ${ }^{231}$ Its analysis of the underlying due process violation was limited to four short paragraphs, in which the Court did not distinguish between procedural and substantive due process. ${ }^{232}$ The single time it used the term "due process" there it did not modify or identify it as "substantive" or "procedural." ${ }^{233}$ The only use of those modifiers was to say, "Public high

229. Id. at 143-44 (Hamilton, J., concurring).

230. Id. at 143 (citation omitted).

231. See supra notes $155-60$ and accompanying text.

232. See Wood v. Strickland, 420 U.S. 308, 322-26 (1975).

233. Id. at 323 . 
school students do have substantive and procedural rights while at school.",234

Second, in the final section of the opinion, the Court did distinguish between procedural and substantive due process, but only to clarify remand instructions, not to make a doctrinal point. The respondents had raised a procedural due process claim before the Supreme Court and, while they had also raised the claim below, the court of appeals did not reach a procedural due process conclusion because it had found a substantive due process violation. ${ }^{235}$ The Supreme Court simply pointed out that on remand the court of appeals is free to reconsider that issue. $^{236}$

Third, while the Court indicated that the lower court erred in its analysis (which was apparently a substantive due process analysis), the Court was vague as to whether the error was in the standard of review, the substantive legal standard, or something else. The Court began by suggesting that the lower court's error was in importing a sufficiency of evidence standard from criminal law into the school context, ${ }^{237}$ but the Court then indicated that it need not address that issue because the lower court had "erroneous[ly] [construed] ... the school regulation in question." 238 The lower court should have deferred to the school district's stated interpretation of the regulation. ${ }^{239}$ Here, the implied legal principle is that districts are owed deference in their construction of discipline codes.

The fact that the lower court completely ignored the school's interpretation relieved the Court of any need to explain or state what the controlling deference standard should be. Unless one assumes Wood requires complete deference under all circumstances, the absence of a standard defining the extent of deference owed to districts renders Wood's holding of little assistance in subsequent adjudications. Likewise, the Court did not reach the fundamental substantive due process question of whether there are any limits on the regulations a district might adopt. It simply pointed out that, under the proper construction of the regulation, the evidence supported the charge against the students and it is not the role of courts to conduct a new factual

234. Id. at 326 .

235. Id. at $326-27$.

236. Id. at 327 .

237. Id. at 322-23.

238. Id. at 324 .

239. Id. at 325 . 
hearing on the merits of the punishments. ${ }^{240}$ In short, Wood only offered two negative directives to lower courts-do not engage in de novo interpretations of school regulations and do not reopen the facts regarding the underlying discipline-neither of which indicates courts should entirely refrain from reviewing discipline and neither of which tells courts anything of the standard of review that they should apply.

Fourth, one might argue that the Court's reversal of the lower court's substantive due process holding, along with the Court's failure to articulate a standard, implied that substantive due process analysis does not apply to school discipline. But that notion is irreconcilable with the Court's explicit statement and citation that students have "substantive and procedural rights." ${ }^{241}$ Equally important, substantive due process is a generally applicable constitutional protection. ${ }^{242}$ It is hard to imagine a rationale by which the Court could completely exempt a subject matter from its scrutiny. Substantive due process review might be more deferential in some areas than others ${ }^{243}$ but some level of scrutiny still necessarily applies. Even if such a rationale exists, the Court in Wood makes no mention of it. In short, in the absence of an explicit holding foreclosing substantive due process review in Wood, it is inappropriate for lower courts to forgo that review.

\section{E. The InCREASIng Disengagement of Courts In Discipline}

In the decades following Goss, courts have surprisingly grown even less willing to seriously entertain discipline claims, whether under procedural or substantive due process. Whatever one makes of a particular court's rationale, the overall trend has been to reject more and more student claims. Richard Arum's study found that a student's chance of prevailing in court on a discipline claim in 1990 was at its lowest point since 1960 (a decade and a half before Goss was decided). ${ }^{244}$ Eight years before Goss in 1967, the probability of student victory was forty-

240. Id. at 326 .

241. Id.

242. See generally Ronald Turner, On Substantive Due Process and Discretionary Traditionalism, 66 SMU L. REV. 841, 842-43 (2013) (discussing the well-established concept of substantive process and the acquiescence of even the most conservative wings of the Court).

243. See Washington v. Glucksberg, 521 U.S. 702, 755-65 (1997) (articulating the varying different levels of scrutiny and the contexts in which they have been applied).

244. ARUM, supra note 85, at 88 . 
nine percent. ${ }^{245}$ Less than a decade after Goss, it had fallen to thirty-nine percent and by 1990 it was thirty-five percentlower than in any year in the study prior to Goss. ${ }^{246}$

A later study by Youssef Chouhoud and Perry Zirkel revealed an even bleaker picture in more recent years. Relying on a different methodology, they distinguished between the types of claims students made and whether a court decision was on the merits of a student's claims. ${ }^{247}$ During the 1990 s and $2000 \mathrm{~s}$, they found that students secured conclusive victories about ten to twenty percent of the time, while schools secured conclusive victories about seventy-five percent of the time. ${ }^{248}$ Moreover, student victories were more often on technical grounds rather than substantive. ${ }^{249}$ Ironically, both studies also found that students' chances were worse in federal than state court. ${ }^{250}$

None of this data definitively speaks to whether courts are dismissing otherwise valid claims, but the declining chances of success after the recognition of student rights in Goss is, at least, curious. It is possible that plaintiffs and lower courts had caught districts off guard by enforcing due process rights before Goss explicitly recognized them, ${ }^{251}$ which would have elevated

245. $I d$

246. Id.

247. Chouhoud \& Zirkel, supra note 17, at 366-68.

248. Id. at 372 .

249. Id. at 377-78 ("In contrast to the steadily increasing pattern in overall frequency, the pattern for overall outcomes on an issue by issue basis is rather steady-and, for students, quite bleak. Indeed, the situation for plaintiffstudents is even darker than the overall PDP outcomes indicate given that: (1) these data do not include the completely adverse results for students in the cases where the court regarded the disciplinary action or effect as de minimis, and (2) the comparatively few conclusive rulings in favor of the student often yielded nominal remedies, including a remand to the school board for a new hearing." (footnotes omitted)).

250. See ARUM, supra note 85, at 92 (indicating that state courts are more likely to find for student-plaintiffs than federal courts in cases where student misbehavior did not involve political action); Chouhoud \& Zirkel, supra note 17 , at $372-74$.

251. See, e.g., Hagopian v. Knowlton, 470 F.2d 201, 211 (2d Cir. 1972), overruled by Phillips v. Marsh, 687 F.2d 620 (2d Cir. 1982); Esteban v. Cent. Mo. State Coll., 415 F.2d 1077, 1089 (8th Cir. 1969); DeJesus v. Penberthy, 344 F. Supp. 70, 74 (D. Conn. 1972) (discussing previous cases recognizing and enforcing due process rights in a public-supported educational setting); Fielder v. Bd. of Educ., 346 F. Supp. 722, 729 (D. Neb. 1972); Whitfield v. Simpson, 312 F. Supp. 889, 897 (E.D. Ill. 1970); Buck v. Carter, 308 F. Supp. 1246, 1249-50 (W.D. Wis. 1970); Vought v. Van Buren Pub. Sch., 306 F. Supp. 1388, 1392-93 (E.D. Mich. 1969); Stricklin v. Regents of Univ. of Wis., 297 F. Supp. 416, 420 (W.D. Wis. 1969). 
plaintiff victory rates. This, however, would only explain a short-term decline in plaintiff success rates after Goss. It would not explain why rates continued to decline in the 1980s and 1990s.

It is also possible that plaintiffs are simply filing more frivolous or poorly conceived cases, but this appears unlikely given that the number of discipline cases filed each year has been relatively constant and always been very small. ${ }^{252}$ The better explanation is an increased negative judicial temperament toward discipline cases and the compounding effect of the precedent those courts set. Prior to Goss, it was not unusual for courts to expect a school to justify its disciplinary action. ${ }^{253}$ Today, courts routinely reject claims with no more than two or three lines of due process analysis. ${ }^{254}$

\section{THE MANDATE OF SUBSTANTIVE DUE PROCESS: ACCOUNTING FOR RELEVANT DISTINCTIONS, INNOCENCE, INDIVIDUALIZED FACTORS, AND DELIBERATION}

Serious doctrinal consideration, rather than abdication or concession, would reveal that zero tolerance and harsh discipline are not without meaningful constitutional limitations and solutions. This is not to suggest that zero tolerance or harsh discipline is per se unconstitutional. To the contrary, the Constitution does not prohibit schools from expelling students for drugs, weapons, and the like. Nor does it prohibit schools from suspending students under circumstances that most would think unwise. Moreover, the Constitution does not grant courts the authority to second-guess the reasoned and logical judgment of schools. But it does not follow, as some assume, that schools can punish students whenever they choose for whatever they choose. Constitutional principles and logical application of them prohibit disciplinary practices that are lacking in reason, logic, judgment, or justification.

252. The Arum study was based on forty-five to seventy published opinions a year. See ARUM, supra note 85, at 52-53. The Zirkel study, because of different methodology, included less. See Chouhoud and Zirkel, supra note 17, at 363-66.

253. See, e.g., Lee v. Macon Cnty. Bd. of Educ., 490 F.2d 458, 460 (5th Cir. 1974); Ladson v. Bd. of Educ., Union Free Sch. Dist. No. 9, Hempstead, 323 N.Y.S.2d 545 (N.Y. Sup. Ct. 1971); Jacobs v. Benedict, 316 N.E.2d 898, 901 (Ohio Ct. App. 1973).

254. See, e.g., Dunn v. Fairfield Cmty. High Sch. Dist. No. 225, 158 F.3d 962, 966 (7th Cir. 1998). 
The locus of these principles is primarily, but not exclusively, substantive due process. Substantive due process is unfortunately one of the most controversial and least definitive areas of constitutional law. ${ }^{255}$ As such, it has the danger of serving as a playground through which the Court imposes any rules and policies it likes. The Court used substantive due process to intervene repeatedly under highly suspect circumstances during the Lochner era, articulating a "right to contract" that trumped scores of state and federal regulations aimed at protecting the poor and stabilizing the economy. ${ }^{256}$ The interventions were so inconsistent that the Court appeared to be operating on whims. ${ }^{257}$ The fear of returning to such an era has colored the Court's perception of substantive due process ever since. ${ }^{258}$ Nonetheless, the Court has since relied on substantive due process to recognize (and reject) some of the most controversial fundamental rights to come before it, such as the right to privacy and abortion. ${ }^{259}$ At the same time, in other areas, the Court has shied away from articulating rigorous standards that would operate as meaningful checks on seemingly mundane state actions, such as negligent or reckless police behavior in the pursuit and detention of criminal suspects. ${ }^{260}$ This history understandably dissuades lower courts from looking to substantive due process to resolve problems of school discipline.

This Article's thesis, however, does not require courts to wade into the politics or indefiniteness of substantive due process. No new grand theory of substantive due process is necessary for courts to limit egregious disciplinary policies. It is enough to recognize basic existing principles that are either explicit or implicit in substantive due process and apply them to the disciplinary policies of schools. The difficulty is that all but a few courts have yet to seriously engage in substantive analysis of school discipline. ${ }^{261}$ Thus, the precedent is sparse at best. Nonetheless, schools are subject to the same Due Process Clause and logic requirements as other state actors, ${ }^{262}$ and certain principles stretch across most all contexts. The task of the

255. Richard H. Fallon, Jr., Some Confusions About Due Process, Judicial Review, and Constitutional Remedies, 93 CoLUM. L. REV. 309, 314 (1993).

256. Rutherford, supra note 137, at 12.

257. See id. at 12-13.

258. Levinson, supra note 22 , at 526 .

259. Rutherford, supra note 137, at 25.

260. See, e.g., Daniels v. Williams, 474 U.S. 327, 327, 332-36 (1986).

261. See supra Part II.D-E.

262. Goss v. Lopez, 419 U.S. 565, 574 (1975). 
remainder of this Article is to identify these limiting constitutional principles and logical constraints.

The following Sections identify four distinct substantive due process principles that place limits on zero tolerance policies and harsh discipline. Section A addresses the problem of treating dissimilar individuals as though they are the same. Of course, all individuals are dissimilar in some respect, but when individuals are dissimilar in respects that are of central relevance to their alleged misconduct, it is irrational to ignore those dissimilarities. Building on Section A, Section B focuses on innocence, demonstrating that substantive due process prohibits the state from harshly punishing individuals who (1) have not breached the letter of the law; or (2) have not engaged in normatively (whether morally, socially, or practically) objectionable behavior. Section $C$ considers the innocence principle in the context of zero tolerance policies. Section D explains that to appropriately distinguish dissimilar individuals, avoid punishing the innocent, and reach rational results, substantive due process requires the state to consider three factors in the context of imposing punishment: the intent of the alleged, the culpability of the alleged, and the harm caused or posed. Section $\mathrm{E}$, the fifth and final Section, further explains that the state cannot simply feign attention to intent, culpability, and harm by presupposing their existence (unless there is a strong basis in experience or logic for doing so), nor can it preclude factual deliberation of these issues.

\section{A. TREATING SigNifiCANTLY DissimilaR INDIVIDUALS THE SAME IS IRRATIONAL}

At some point, individuals are so dissimilarly situated that it is irrational to treat them the same. Both due process and equal protection rest on the fundamental principle that the government must treat similarly situated individuals the same way. ${ }^{263}$ This principle rests most obviously in equal protection doctrine. There, equity limits differential treatment based on immutable, illegitimate, or irrational differences between individuals. ${ }^{264}$ Because most of the inequities that courts have confronted in the past-racial, gender, disability, poverty, etc.fall easily within the framework of equal protection, litigants and courts instinctively move to that analysis. But equal

263. Deana Pollard Sacks, State Actors Beating Children: A Call for Judicial Relief, 42 U.C. DAVIS L. REV. 1165, 1217 (2009).

264. United States v. Carolene Prods. Co., 304 U.S. 144, 153-54 (1938). 
treatment inheres in due process as well, as inequity operates contrary to the rationality that due process requires. ${ }^{265}$ As such, the Supreme Court in Bolling $v$. Sharpe ${ }^{266}$ held that due process rights include the guarantee of equal treatment. The Court explained:

[T] he concepts of equal protection and due process, both stemming from our American ideal of fairness, are not mutually exclusive. The "equal protection of the laws" is a more explicit safeguard of prohibited unfairness than "due process of law," and, therefore, we do not imply that the two are always interchangeable phrases. But, as this Court has recognized, discrimination may be so unjustifiable as to be violative of due process. ${ }^{267}$

For the purposes of this Article, the most important aspect of equity in due process is not ensuring that similarly situated individuals are treated the same, but the inverse. If treating similarly situated students differently violates due process, then treating dissimilarly situated students as though they are the same also violates due process. Consider, for instance, disciplinary proceedings or policies aimed at identifying and punishing misbehaving students. It would be irrational to treat two otherwise violent students differently simply because they wore different colored shirts on the day in question. In the same way, it would be irrational to treat a non-violent student and a violent student as though they were the same simply because they both wore blue shirts on the day in question. Fortunately, the real world belies such simple problems and examples. A single state action may include multiple relevant factors and the definition of "similarly situated" would vary accordingly. Thus, a more accurate statement of the equality principle forwarded here would be that substantive due process is violated when either individuals are similarly situated in relevant respects, but treated differently, or individuals are dissimilar in relevant respects, but treated the same.

To flesh out the foregoing further, treating dissimilar individuals the same violates due process for, at least, three related but distinct reasons. First, putting formal equality concerns

265. Laurence Tribe refers to and analyzes equal protection and due process as a "double helix." Laurence H. Tribe, Lawrence v. Texas: The "Fundamental Right" That Dare Not Speak Its Name, 117 HARV. L. REV. 1893, 1898 (2004); see also Harvey v. Horan, 285 F.3d 298, 318-19 (4th Cir. 2002) (pointing out that there is no hermetic line between the substantive and the procedural in due process analyses); Kenji Yoshino, The New Equal Protection, 124 HARV. L. REV. 747, 748 (2011)

266. 347 U.S. 497 (1954)

267. Id. at 499 . 
aside, it is irrational to treat meaningfully dissimilar things as though they are the same simply because they share some characteristic. ${ }^{268}$ Both shovels and chainsaws have bladed tips and similar curvatures at their ends, but choosing to dig a grave with a chainsaw or cut down a mature oak tree with shovel would be irrational under almost any circumstance one would bother to imagine, even though one could theoretically dig a grave or cut down a tree with either. The items are too dissimilar in other meaningful respects for one to fashion a logic, under normal circumstances, by which to treat them the same.

Second, it is irrational to disregard relevant circumstances. ${ }^{269}$ Both the similar and dissimilar treatment in the above discipline example rest on irrelevant factors and disregard the most relevant factor. Unless a school has a dress code, the color of students' clothing is an irrelevant factor in assessing student behavior, whereas violence is relevant. But the example involved the school basing its decision on the former and ignoring the latter. The key is the relevance of the factors ignored and considered. To be clear, it is not always irrational to treat dissimilar people the same. In fact, it may be quite rational in certain circumstances. School teachers, for instance, are rational in teaching students with blonde hair to read the same way that they teach students with brown hair. But teachers are irrational if they teach dyslexic students to read in the same way they teach non-dyslexic students. In short, irrational treatment occurs when the treatment is disconnected from the relevant characteristics that justify the treatment. ${ }^{270}$

268. See, e.g., Plyler v. Doe, 457 U.S. 202, 216 (1982); Tigner v. Texas, 310 U.S. 141, 147 (1940); Kenneth W. Simons, The Logic of Egalitarian Norms, 80 B.U. L. REV. 693, 727 (2000); see also ANTOINE ARNAUld \& PiERRE NiCOlE, LOGIC OR THE ART OF THINKING 135-36 (Jill Vance Buroke ed. \& trans., 1996) (explaining the logical fallacy of inferring a connection between multiple items based on incomplete suppositions); RICHARD A. POSNER, THE ECONOMICS OF JUSTICE 48, 75 (1981) (discussing the logic of law, its treatment of like things, and its assessment of similar and different things).

269. See generally MAX BLACK, CRITICAL THINKING 14-15 (2d ed. 1952) (discussing the necessity of accounting for relevant facts).

270. The Court, although relying on the Sixth Amendment right to a jury, has struck down mandatory sentencing regimes on analogous grounds. In Blakely $v$. Washington, 542 U.S. 296 (2004), the Court emphasized that certain aspects of a crime are inherently relevant to violation of that crime and, thus, the jury must decide them. It was therefore beyond the power of the legislature to take those inquiries away from the jury and assign them to the judge. Id. at 306-07. In Jones v. United States, 526 U.S. 227 (1999), to avoid a similar problem, the Court likewise inferred that harm to the victim was an element 
Third, treating dissimilar individuals the same produces arbitrary results - a key marker of a substantive due process violation $^{271}$-rather than calculated results. If the factors relied upon are irrelevant, they may also be random. For instance, if a school punished a well-behaved student simply because the student shared the characteristic of wearing a blue shirt with a misbehaving student, it could just as easily punish a student for a red, yellow, or purple shirt. Treatment based on irrelevant factors becomes as random and arbitrary as drawing names out of a hat or being struck by lightning. Due process history, motivations, and precedent are explicit in their prohibition against arbitrary results. ${ }^{272}$

With that said, it is not uncommon for the government to focus on factors that are one or more steps removed from the most relevant factor(s). For instance, the government in the effort to protect our water supply might cast a wide net and pass a rule prohibiting the pouring of any liquid into our water supply outdoors. This would capture both the polluter and the person washing his dog in the back yard or tossing out spoiled milk. The intent of the broad net would be to ensure the ensnarement of the toxic polluter, but if the intent did not include ensnaring the milk-tosser, the rule would be irrational in design because it was aimed too broadly at a benign activity simply because it corresponded in some way with independent problematic activity. By focusing on a factor that was related but too far attenuated from the primary problematic activity of polluting, the rule would produce random and, hence, irrational results. All punished under the rule would have poured something, but if the rule was enforced evenhandedly against all pourers, the punished class would likely be no more significantly populated by "polluters" than any other class of individuals one might randomly identify in society. ${ }^{273}$ As one court wrote of students who drank from a punchbowl that had been secretly

of the crime even though the statute did not identify it as such. Id. at 232 .

271. See, e.g., Hurtado v. California, 110 U.S. 516, 527 (1884) (indicating the purpose of due process is to prevent "arbitrary exercise of the powers of government").

272. Fallon, supra note 255, at 310 .

273. If the rule was evenhandedly enforced, the harmless pourer would likely alter his behavior and no longer be subject to punishment, leaving the polluter as the only penalized group. In this respect, the law would have achieved its pollution goal, but in the process, it would have arbitrarily restricted the liberty and freedom of many innocent citizens. That a law might further a desirable end does not make it rational if it also produces numerous other random or arbitrary ends. 
spiked with alcohol, suspending those students "would not rationally advance the school's legitimate interest in preventing underage students from drinking alcohol on school premises any more than suspending a handful of students chosen at random from the school's directory." ${ }^{274}$ In short, government action is random and arbitrary when it is based on factors insufficiently related to its goals, even if those factors correspond in some respect to its goals. The more difficult question is determining the point at which a factor is sufficiently irrelevant or relevant that consideration or neglect of the factor renders a governmental decision random or arbitrary. At this point, however, it suffices to consider the foregoing principles' operation in the most important context: "the innocent."

\section{B. PUNISHING INNOCENT INDIVIDUALS Is IRRATIONAL}

Process and rules that by design punish or allow for the punishment of the innocent violate due process. ${ }^{275}$ Process, of course, cannot be flawless and will inevitably punish the innocent. That punishment would be considered an error, ${ }^{276}$ and this Article does not suggest that errors are presumptive violations of due process. Rather, the principle forwarded here is that a state process or rule that claims to have reached the correct result for an individual, even though the state knew or should have known an individual was innocent, violates substantive due process. First, the state lacks a legitimate goal for intentionally punishing the innocent. ${ }^{277}$ Second, while the state might claim that its legitimate goal is punishing the guilty and the punishment of some innocent individuals is incidental and

274. Seal v. Morgan, 229 F.3d 567, 578 (6th Cir. 2000).

275. See, e.g., People v. Washington, 665 N.E.2d 1330, 1336-37 (Ill. 1996); State ex rel. Holmes v. Court of Appeals, 885 S.W.2d 389, 397-98 (Tex. Crim. App. 1994). See generally Ursula Bentele, Does the Death Penalty, by Risking Execution of the Innocent, Violate Substantive Due Process?, 40 HOUS. L. REV. 1359 (2004) (analyzing innocence in the context of substantive due process). In Herrera $v$. Collins, Justice Blackmun, joined by Justices Souter and Stevens, stated definitively: "Nothing could be more contrary to contemporary standards of decency or more shocking to the conscience than to execute a person who is actually innocent.” 506 U.S. 390, 430 (1993) (Blackmun, J., dissenting) (citations omitted). The three dissenting justices agreed with Justice O'Connor's concurring opinion on this point. See id. at 419 (O'Connor, J., concurring).

276. See Mathews v. Eldridge, 424 U.S. 319, 344 (1976).

277. See, e.g., Seal, 229 F.3d at 578; see also Susan Bandes, Simple Murder: A Comment on the Legality of Executing the Innocent, 44 BUFF. L. REV. 501, 503 (1996). 
necessary to that goal, that incidental punishment is only justifiable and rational if it is accidental, not intentional or in reckless disregard for innocence. ${ }^{278}$

By "innocent," this Article means individuals who (1) have not breached the letter of the law; or (2) have not engaged in normatively (whether morally, socially, or practically) objectionable behavior. ${ }^{279}$ Extensive scholarship, of course, has been devoted to what norms are just. ${ }^{280}$ This Article makes no pretense of evaluating those competing norms and, instead, proceeds based on the approach that our laws and Constitution have, as a practical matter, taken. Our laws primarily rest upon a normative approach that defines innocence and guilt in terms of mental culpability. ${ }^{281}$ A person's actions alone are almost never sufficient to justify punishment, as the person has not engaged in what society deems repugnant behavior. For instance, it is not a crime to kill someone. It is a crime to kill someone when it is done with certain types of intent.

The only instances in which our laws diverge from this approach are where the punishment is minimal or the behavior is

278. See Bentele, supra note 275 , at 1368 .

279. To avoid a huge divergence into innocence, this Article's explanation of what it means to be innocent or "otherwise innocent" grossly oversimplifies the issue. To be slightly clearer, the Court, while espousing a commitment to innocence, has upheld strict liability in some instances. Alan Michaels offers a thorough analysis of the Court's jurisprudence and a more refined articulation of the constitutional limits of punishing the innocent:

According to the principle of constitutional innocence, strict liabil-

ity is constitutional when, but only when, the intentional conduct covered by the statute could be made criminal by the legislature. In other words, strict liability runs afoul of the Constitution if the other elements of the crime, with the strict liability element excluded, could not themselves be made a crime. Otherwise, strict liability is constitutional.

Alan C. Michaels, Constitutional Innocence, 112 HARV. L. REV. 828, 834 (1999).

280. See, e.g., Gary V. Dubin, Mens Rea Reconsidered: A Plea for a Due Process Concept of Criminal Responsibility, 18 STAN. L. REV. 322 (1966); C. Peter Erlinder, Mens Rea, Due Process, and the Supreme Court: Toward a Constitutional Doctrine of Substantive Criminal Law, 9 AM. J. CRIM. L. 163 (1981); Keith A. Findley, Defining Innocence, 74 ALB. L. REV. 1157 (2011); John Calvin Jeffries, Jr. \& Paul B. Stephan III, Defenses, Presumptions, and Burden of Proof in the Criminal Law, 88 YALE L.J. 1325 (1979); Laurie L. Levenson, Good Faith Defenses: Reshaping Strict Liability Crimes, 78 CORNELL L. REV. 401 (1993); Michaels, supra note 279.

281. See generally Kennedy, supra note 34, at 761 (explaining the Court's treatment of mens rea and balancing blameworthiness of mental state with severity of punishment). 
inherently problematic or speaks for itself. ${ }^{282}$ Where the punishment is minimal, an assessment of culpability may not be worth the individual's or society's time. ${ }^{283}$ In other instances, the behavior necessarily carries the requisite mental culpability and, thus, does not warrant special inquiry. ${ }^{284}$ Both points are bound up in prohibitions on operating cars in excess of the speed limit. Operating a car in excess of the speed limit poses the same risks and threats to the public, regardless of whether it is accidental or intentional. Thus, low level regulatory crimes of this sort do not include culpability requirements. With that said, punishing the normatively innocent remains a concern and, even in the context of speeding, our laws and courts would narrowly construe "operating," so as to exclude the "innocent" from punishment. A person driving a run-away speeding Prius is not necessarily "operating" a car. Thus, even a law that lacks an explicit culpability component tends to be construed as including one.

\section{Zero TOLERANCE DisRegards SignifiCANT DistinCtions AND INNOCENCE}

Zero tolerance policies vary by state and locality. Many surely include nuances that allow them to be applied constitutionally. But many, either in form or function, treat dissimilarly situated students as though they are the same. Aggressive zero tolerance policies lump various categorically different types of behavior together. ${ }^{285}$ These categories of behavior range from trivial to serious misbehavior, and illegal behavior to behavior that is neither illegal nor normatively problematic. For instance, alcohol, tobacco, and drug offenses, which include possession, consumption, intoxication, and sales, are typically lumped together. ${ }^{286}$ All of these items and activities are rightly off limits for students on school grounds and this Article does not question that they can be punished. But these items and

282. Id. at $835-36$.

283. Cf. id. at 781-82, 835-36 (discussing how, in some cases, danger to society allows for a low mens rea requirement).

284. See id. at 841, 853-54 (discussing how sentencing should take into account those that are morally innocent and further discussing a theory that those that act immorally should still be punished, even if they believed their behavior was legal).

285. Kim Fries \& Todd A. DeMitchell, Zero Tolerance and the Paradox of Fairness: Viewpoint from a Classroom, 36 J.L. \& EDUC. 211, 213, 222 (2007).

286. See ADVANCEMENT PROJECT, supra note 60, at 15; Fries \& DeMitchell, supra note 285 , at 213 . 
activities are not the same. The student who regularly sells drugs to his classmates in the school parking lot is far different from the student who consumes marijuana, given to him by his wayward uncle, in the basement of his own home. Both students may have engaged in a crime, but in some locations the latter may have committed no more than a minor misdemeanor that carries a fine ${ }^{287}$ whereas the former may have committed a serious felony. ${ }^{288}$ Equally, if not more important, the latter would not have involved or endangered anyone but himself, nor would he have entered school property, whereas the former would have transgressed all three factors. Zero tolerance policies, however, often disregard distinctions between on-campus and off-campus behavior, ${ }^{289}$ as well as distinctions between serious and relatively minor misbehavior. ${ }^{290}$

One might allow that, while distinct, all illegal activities are sufficiently serious that they warrant the same response from schools and, thus, schools need not parse them out. Even if that rationale could be substantiated-which it probably cannot-it does not justify the breadth of some zero tolerance policies. Alcohol and tobacco are legal items and, under certain circumstances, a student might have legal access to them outside of school. ${ }^{291}$ Minors' access to items such as ibuprofen, aspirin, cough drops, and other over-the-counter "drugs" is relatively broad. In contrast, items such as cocaine and marijuana are controlled substances that neither adults nor minors can legally obtain (outside of Colorado and Washington and those states that permit its medicinal use) ${ }^{292}$ None of this is to suggest that schools should permit students to bring any of these items to school, but attending school with alcohol or nicotine in one's system or ibuprofen in one's pocket is far different than having

287. See, e.g., D.C. CoDE $§ 48-904.01$ (2014); see also Aaron C. Davis, D.C. Poised for a Giant Leap Toward Legalizing Small Amounts of Marijuana, WASH. POST (Oct. 24, 2013), http://www.washingtonpost.com/local/dc -politics/dc-poised-for-giant-leap-toward-legalizing-marijuana/2013/10/24/ db183fb0-3cbe-11e3-b6a9-da62c264f40e_story.html.

288. See, e.g., ARIZ. REV. STAT. ANN. § 13-3411 (2009); see also D.C. CODE $\S 48-904.07 \mathrm{a}(2014)$.

289. See, e.g., TENN. CODE ANN. § 49-6-3401 (2014) (giving principals the power to suspend students for being charged with a felony off school grounds).

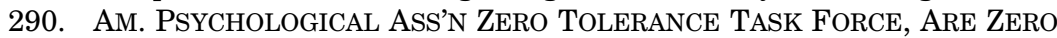
TOLERANCE Policies EFFECTIVE IN THE SCHOOLS? AN EvidENTIARY REVIEW AND RECOMMENDATIONS 31 (2006), http://www.apa.org/pubs/info/reports/zero -tolerance-report.pdf.

291. See, e.g., OHIO REv. CodE ANN. § 4301.69 (LexisNexis 2006).

292. 21 U.S.C. $\S 841(2012)$. 
a controlled substance in one's system. The latter would by necessity have engaged in illegal activity, whereas the former would not have.

Consider the student whose parents allowed him a glass (or two) of wine to celebrate some significant event the night before school or cough drops and ibuprofen to control a cold at school versus the student who purchased and smoked marijuana in the school parking lot before entering school. By their text, most zero tolerance policies would treat the aforementioned wine drinking or ibuprofen and cough drop carrying student the same as the pot smoker. ${ }^{293}$ Some would treat the wine drinking student the same, even if he did not enter school with alcohol in his system. At least one school that made national news did not even premise its zero tolerance policy toward alcohol on consumption. It was enough that a student was involved in an alcohol incident, by which the school simply meant being in the presence of alcohol consumption. ${ }^{294}$ Egregious examples such as these, even if rare, reveal the irrationality of zero tolerance policies that refuse to distinguish between the legal and illegal, the serious and trivial, on- and off-campus behavior, and the innocent and culpable.

The lack of distinction between the legal and illegal, or dangerous and non-dangerous activity, is even more problematic in zero tolerance's approach to weapons. Policies often define a weapons offense in the broadest sense possible_-"possess[ing] any item capable of inflicting injury or harm (hereinafter referred to as a weapon) to persons or property" ${ }^{\prime 25}$ - and punish all offenses with long-term suspension or expulsion. ${ }^{296}$ The obvious intent of a broad definition of "weapon" (or "drug") is to err on the side of safety and sweep in as much conduct as possible. Legitimate safety motivations, however, do not sanction irrational policies and implementation. Broad definitions treat

293. Blumenson \& Nilsen, supra note 18, at 71-72 (discussing the broad interpretation of drugs, alcohol, and weapons in school policies); see also Fries \& DeMitchell, supra note 285, at 107 (discussing the broad interpretation of weapons).

294. Black, supra note 4; Murphy, supra note 1; see also supra notes 1-4 and accompanying text. To be fair, the punishment under this particular policy related to participation in sports, not expulsion from school, Murphy, supra note 1 , but the same irrationality is present nonetheless.

295. See, e.g., GREenVILle CNTY. SCH., POLICIES § JCDAA (2008), available at http://www.boarddocs.com/sc/greenville/Board.nsf/Public (enter "Policies" tab; then expand "J-Students" section; then select "JCDAA: Weapons in School").

296. See, e.g., id. 
benign or "innocent" behavior as equivalent to malevolent violence. Some school districts have deemed key-chains, staplers, geometry compasses, and finger nail clippers as weapons, and expelled students for merely possessing them. ${ }^{297}$ No doubt, circumstances could arise in which these items are equivalent to weapons, but those circumstances would involve a student using or intending to use the item as a weapon, not simply possessing the item. Zero tolerance policies frequently ignore this crucially relevant circumstance and instead focus on the fact that these items share some quality-sharpness or capacity to harm-with definitive weapons. But sharing a quality with a definitive weapon no more makes a fingernail clipper a weapon than does sharing the characteristic of insanity with the Unabomber make one a terrorist. ${ }^{298}$

None of this is to say that a school might not permissibly and explicitly prohibit bringing fingernail clippers to school, but it does not follow that a school can still treat and punish them as though they are weapons. Because fingernail clippers are benign, legal, and particularly useful items, there are any number of ways that a student may accidentally bring such an item to school. Even though the school might confiscate or impose some minor punishment, no rationale exists by which to punish the accidental possession of a benign, legal, and particularly useful item as one would punish the intentional possession of a hunting knife or firearm, by expulsion. To do so is to irrationally (1) merge non-weapons with weapons, and (2) presume a high level of culpability or intent based on possession where none likely exists.

This merger and presumption also necessarily make the "innocent" subject to mandatory expulsion. The only way by which to characterize the student who accidentally brings fingernail clippers or cough drops to school as something other than innocent is to imagine a strict liability totalitarian world

297. Blumenson \& Nilsen, supra note 18 , at 72.

298. It was this exact type of flawed reasoning that lead the Court to strike down the detention of an alleged enemy combatant in Hamdi v. Rumsfeld, 542 U.S. 507 (2004), as a violation of due process. While Hamdi shared the characteristic of having been seized in Afghanistan-if not the battlefield-with a larger class of individuals who posed a threat to the United States or its soldiers, this fact alone could not render Hamdi an enemy combatant or foreclose the need to inquire further into his situation. $I d$. at 527 (plurality opinion). To focus solely on that characteristic would fail to account for individuals who are clearly not enemy combatants: "errant tourist[s], embedded journalist[s], or local aid worker[s]." Id. at 534. 
in which conduct is permissible or impermissible, not based on policy or reason, but based on the fact that the government has "said so." But in our democratic and constitutional regime, and even if the context of schools that have far more responsibility and latitude for shaping student character, our courts have repeatedly rejected the notion that government or schools can operate as totalitarian regimes. ${ }^{299}$

Some would, nonetheless, defend policies that punish the innocent as rationally related to the goal of safety. ${ }^{300}$ They reason that strict and inflexible rules, even if they punish the innocent, further safety by leaving no potential threat unpunished..$^{301}$ This reasoning, however, is seriously flawed because the "innocent" student who unknowingly possesses a nail clipper, or even a pocket knife, is not a "potential threat" any more than a student who does not possess a "weapon." Thus, expelling such a student does not, in any way, serve a school's safety goals. As the Sixth Circuit explained:

[S] uspending or expelling a student for weapons possession, even if the student did not knowingly possess any weapon, would not be rationally related to any legitimate state interest. No student can use a weapon to injure another person, to disrupt school operations, or, for that matter, any other purpose if the student is totally unaware of its presence. $^{302}$

The Supreme Court has further emphasized in other contexts that unchecked and undifferentiated punishment of individuals "carries the potential to become a means for oppression and abuse of others who do not present th[e] sort of threat" the government is seeking to eliminate. ${ }^{303}$

What the school is really asserting when it punishes the "innocent" is not an interest in safety, but in convenience or efficiency. Without question, it is more convenient to punish

299. See, e.g., Goss v. Lopez, 419 U.S. 565, 574 (1975); Tinker v. Des Moines Indep. Cmty. Sch. Dist., 393 U.S. 503, 511 (1968); see also Hamdi, 542 U.S. at 530,535 (plurality opinion) (warning that government action unchecked by fair and full due process can "become a means of oppression," and rejecting the government's assertion that judicial review of individual cases would interfere with its overall execution of national policy).

300. Deborah Gordon Klehr, Addressing the Unintended Consequences of No Child Left Behind and Zero Tolerance: Better Strategies for Safe Schools and Successful Students, 16 GEO. J. ON POVERTY L. \& POL'Y 585, 588-90 (2009) (discussing the rationale of safe schools and zero tolerance).

301. This rationale draws on the broken windows theory of policing. See generally James Q. Wilson \& George L. Kelling, Broken Windows, ATLANTIC MONTHLY, Mar. 1982, at 29.

302. Seal v. Morgan, 229 F.3d 567, 575 (6th Cir. 2000).

303. Hamdi, 542 U.S. at 530 (plurality opinion). 
based on predicate facts that correspond with threatspossessing a sharp object for instance-than based on actual threats themselves. But efficiency alone is not a legitimate basis to punish the innocent, particularly when the innocent are readily distinguishable. The very purpose of due process is to separate the "guilty" from the "innocent," and draw reasonable distinctions between those to be regulated. ${ }^{304}$ A rule that lumps the guilty and innocent into a single category simply to ease the burden of due process serves no legitimate goal. ${ }^{305}$

Efficiency serves as a legitimate interest in determining how much process a government actor should afford, but not in limiting the key inquiries process must pursue. For instance, courts have held that allowing a student to be represented by an attorney and cross-examine witnesses imposes too much of a burden on a school, particularly in regard to a short-term suspension. ${ }^{306}$ But even if attorneys and cross-examination are too burdensome, no court has ever suggested that a school, so long as it held some type of informal hearing, could do away with the underlying question of, for instance, which of five students destroyed their teacher's book bag simply because sorting the guilty from the innocent would be burdensome. ${ }^{307}$ Zero tolerance policies that disregard circumstances do exactly that. They dis-

304. See, e.g., Fuentes v. Shevin, 407 U.S. 67, 80-81 (1972); see also 1 KENNETH CULP DAVIS, ADMINISTRATIVE LAW TREATISE $\$ 7.01$ (1958) (discussing due process requirements in the context of administrative law).

305. This idea is also indirectly at play in the Court's Sixth Amendment jurisprudence on mandatory criminal punishment guidelines. In several cases, Congress or a state has taken certain relevant fact finding inquiries away from the jury, asking the jury to only find certain basic predicate facts, and making punishment mandatory upon a jury finding those facts. The Court has found these systems unconstitutional. See, e.g., United States v. Booker, 543 U.S. 220, 230 (2005) (rejecting approaches that would "reduc[e] the jury's role "to the relative importance of low-level gatekeeping"' (citing Jones v. United States, 526 U.S. 227, 244 (1999))); Blakely v. Washington, 542 U.S. 296, 30607 (2004) ("The jury could not function as circuitbreaker in the State's machinery of justice if it were relegated to making a determination that the defendant at some point did something wrong, a mere preliminary to a judicial inquisition into the facts of the crime the State actually seeks to punish." (emphasis omitted)).

306. See e.g., Osteen v. Henley, 13 F.3d 221, 225 (7th Cir. 1993); Newsome v. Batavia Local Sch. Dist., 842 F.2d 920, 925-26 (6th Cir. 1988); Gorman v. Univ. of R.I., 837 F.2d 7, 16 (1st Cir. 1988).

307. Recognizing the state's legitimate interest in preserving its finite resources, the Court has acceded to balancing the risk of error against the burden of more process, but the Court has not suggested that avoiding the question of guilt and innocence is a legitimate means of achieving that end. See generally Mathews v. Eldridge, 424 U.S. 319, 348 (1976). 
regard innocence and the fundamental question that the Court in Goss indicated schools must answer: whether punishment is "warranted." "

Finally, putting aside the problems of broadly defining weapons and drugs, conflating possession with use, and ignoring innocence, many states and schools also extend zero tolerance or expulsion to behavior that cannot under any circumstances be construed as being as serious or egregious as drugs or weapons. For instance, it is not uncommon for disciplinary codes to treat tardiness, disrespect, and defiance as a basis for suspension and expulsion. ${ }^{309}$ Granted, policies do not tend to expel students for one instance of tardiness or disrespect, but repeat instances-two or three-have led to mandatory suspension and expulsion in many districts and states. ${ }^{310}$ While these behaviors warrant a response, disrespect, even if repeated, is in no way equivalent to selling drugs at school. Yet, some schools treat them as such.

South Carolina's disciplinary statute, while not mandating expulsion for these minor behaviors, captures the irrationality. The relevant statute provides that a district may expel, suspend, or transfer "any pupil for the commission of any crime, gross immorality, gross misbehavior, persistent disobedience, or for violation of written rules and promulgated regulations established by the district board, county board, or the State Board of Education." ${ }^{311}$ On its face, it equates a crime with persistent disobedience, authorizing the same maximum penalty for both. It then provides, however, that a district "shall not authorize or order the expulsion, suspension, or transfer of any pupil for a violation of Section 59-150-250(B), ${ }^{, 312}$ which makes it a misdemeanor for a minor to knowingly purchase a lottery game ticket. ${ }^{313}$ In other words, a district may expel a student for disobeying a teacher's instruction on a regular basis, but it may not even suspend a student who commits the misdemeanor of buying a lottery ticket in the middle of math class. Thus, the statute implicitly recognizes the irrational conflation of substantially dissimilar behavior in one instance-selling cocaine versus buying a lottery ticket—but rejects the more obvious

308. Goss v. Lopez, 419 U.S. 565, 579 (1975).

309. See, e.g., COLO. REV. STAT. § 22-33-106 (2014).

310. See, e.g., Miss. CODE ANN. § 37-11-18.1 (2014).

311. S.C. CODE ANN. § 59-63-210(A) (2013).

312. Id. § 59-63-210(B).

313. Id. § 59-150-250(B). 
and pertinent distinctions between the classroom clown and the parking lot criminal. In this respect, the grounds for suspension and expulsion are both over- and under-inclusive, a paradigmatic indicator of irrationality. ${ }^{314}$

D. Substantive Due Process and Rational Decision-

MAKING REQUIRE THE CONSIDERATION OF THREE

INDIVIDUALIZED FACTORS: INTENT, CULPABILITY, AND HARM

The foregoing Sections advanced the general proposition that due process requires the consideration of relevant circumstances, without delineating the precise boundaries of relevance and whether any circumstances are per se relevant. Numerous factors and circumstances are potentially relevant in determining whether and how to punish a student, and they vary according to the behavior and punishment. A school district might have discretion as to whether to consider some factors and circumstances, such as whether a behavior occurred before or during class or whether a student was experiencing trouble in his home life. Factors and circumstances of this sort, while relevant, might be limited or trumped by other factors and circumstances, such as whether the student was to be punished by expulsion or detention. Substantive due process, however, would mandate the consideration of another category of circumstances and factors, at least, when the punishment to be imposed is suspension or expulsion. In particular, a district must consider or account for intent, culpability, capacity, and harm (i.e., danger or disruption to school). As the following subsections will demonstrate, punishment in the absence of these considerations is constitutionally irrational.

1. Intent

The foremost factor in assessing student behavior is intent. The irrationality of disregarding intent is sufficiently egregious that this is the one area where, in contrast to the overwhelming trend of summary affirmance of discipline, a few courts have been willing to intercede. The leading case on point is Seal $v$.

314. The Court, however, has upheld laws that are both under- and overinclusive, reasoning that perfection in the rational relationship "is by no means required." N.Y.C. Transit Auth. v. Beazer, 440 U.S. 568, 592 n.39 (1979) (quoting Phillips Chem. Co. v. Dumas Sch. Dist., 361 U.S. 376, 385 (1960)). But at some point laws are so over- and under-inclusive that they are irrational. See generally ERWIN CHEMERINSKY, CONSTITUTIONAL LAW: PRINCIPLES AND POLICIES 687-89 (4th ed. 2011) (discussing the levels of scrutiny and the rational basis test). 
Morgan. ${ }^{315}$ The case involved the expulsion of a student for driving a car to school that contained a knife. ${ }^{316}$ The knife was not his, and he was unaware that it was in the car. ${ }^{317}$ The board, nonetheless, insisted on his expulsion, and the Sixth Circuit offered a full rejoinder. ${ }^{318}$ First, expelling a student for unknowingly possessing a weapon is "not ... rationally related to any legitimate state interest" because such a student poses no threat to anyone. ${ }^{319}$ Second, "possession" crimes, even when they do not explicitly state intent as an element, "ordinarily impl[y] knowing or conscious possession." ${ }^{, 20}$ Even were that implication missing, courts have indicated that due process prohibits state legislatures from removing intent as an element in crimes. ${ }^{321}$ Third, intent is not some criminal "technicality" but a fundamental precept of substantive due process "so obvious that it would go without saying." ${ }^{322}$ Thus, intent applies to punishment and deprivations other than criminal, including expulsion and suspension. For instance, the court opined that a school could not, consistent with due process, expel a valedicto-

315. 229 F.3d 567 (6th Cir. 2000).

316. Id. at $571-72$.

317. Id.

318. Id. at 581 .

319. Id. at 575 .

320. Id. at 575-76.

321. Id. ("See Wayne R. LaFave \& Austin [W.] Scott, Jr., Substantive Criminal Law § 3.2, at 279 (1986 \& Supp. 2000) (noting that '[f]or legal purposes other than criminal law-e.g., the law of finders-one may possess something without knowing of its existence, but possession in a criminal statute is usually construed to mean conscious possession') (footnotes omitted); see also United States v. Lewis, 701 F.2d 972, 973 (D.C. Cir. 1983) (Bork, J.) (observing that in order [']to withstand a motion for judgment of acquittal on the charge of constructive possession of an illegal firearm,['] the government must introduce sufficient evidence for a reasonable jury to conclude that the possession was "knowing" ') (citation omitted); United States v. Sawyer, 294 F.2d 24, 29 (4th Cir. 1961) (noting, in a prosecution for unlawful possession of inventory for liquor bootlegging, that 'possession, when charged as a crime, must be conscious'); State v. Rice, 172 Conn. 94, 374 A.2d 128, 132 (1976) (concluding, in a prosecution for unlawful carrying of a firearm in a motor vehicle, that constitutional due process requires the government to prove the defendant's knowing possession of the firearm); State v. Labato, 7 N.J. 137, 80 A.2d 617, 62[3] (1951) (noting in a criminal prosecution for possession of illegal lottery tickets, that the state legislature could legitimately abrogate the common law requirement of scienter, or evil intent, and impose criminal liability on persons who did not know that their possession of the tickets was illegal, but could not abrogate the requirement that the persons intentionally possessed the tickets)." (alteration in original)).

322. Seal, 229 F.3d at 576. 
rian who unknowingly had a knife planted in his backpack based simply on his possession of the knife. ${ }^{323}$

While none have joined Seal in recognizing these points so forcefully, the court's rationale is largely unchallenged by other courts. Without suggesting generally applicable substantive due process holdings, a group of courts have sided with Seal and reversed student suspensions and expulsions where intent is lacking. ${ }^{324}$ Those courts that do not follow Seal have stretched to distinguish it, either unquestionably deferring to a school's conclusion that intent existed or independently inferring intent themselves based on the facts. ${ }^{325}$ These courts may outnumber the Seal-leaning courts, but their holdings generally rest on deference to schools and exempting school codes from the strict constitutional rigor applied to the criminal code. These cases do not offer a substantive due process defense or justification for expelling a student who lacked intent, nor could they. ${ }^{326}$ The concept of intent is so rooted in history, logic, and substantive due process that departure from it requires a highly unique or persuasive justification, which is lacking in zero tolerance and harsh discipline.

While not controlling in education, the criminal context, nonetheless, is instructive on the question of intent. ${ }^{327}$ The Supreme Court and lower courts have offered a framework for

323. Id.

324. See Langley ex rel. Langley v. Monroe Cnty. Sch. Dist., No. 1:05CV40, 2006 WL 2850349, at *4 (N.D. Miss. Oct. 2, 2006); Tarkington Indep. Sch. Dist. v. Ellis, 200 S.W.3d 794, 803-04 (Tex. Ct. App. 2006); see also Christopher D. Pelliccioni, Note, Is Intent Required? Zero Tolerance, Scienter, and the Substantive Due Process Rights of Students, 53 CASE W. RES. L. REV. 977, 996 (2003) (arguing that the disregard for intent in zero tolerance is unconstitutional).

325. See, e.g., S.G. ex rel. A.G. v. Sayreville Bd. of Educ., 333 F.3d 417, 425 (3rd Cir. 2003); Butler v. Rio Rancho Pub. Sch. Bd. of Educ., 341 F.3d 1197, 1201 (10th Cir. 2003); Piekosz-Murphy v. Bd. of Educ., 858 F. Supp. 2d 952, 961 (N.D. Ill. 2012); Posthumus v. Bd. of Educ., 380 F. Supp. 2d 891, 899 (W.D. Mich. 2005); Bundick v. Bay City Indep. Sch. Dist., 140 F. Supp. 2d 735, 740 (S.D. Tex. 2001). The only arguable departure from the requirement of intent was in Mitchell v. Board of Trustees, 625 F.2d 660 (5th Cir. 1980), where the court was forceful in upholding a blanket policy regarding weapons on school grounds as being rationally related to safety, but even there, the facts indicated the students possessed intent. $I d$. at 661 .

326. See supra notes 281-84 and accompanying text.

327. While the Court in Wood v. Strickland did not reach the question of whether the lower court had properly applied the due process rationale from a criminal case, the Court implied that this approach was misplaced. 420 U.S. 308, 323-24 (1975). Regardless, this implication was context specific and does not preclude the application of general substantive due process review. 
considering the relevance and role of intent, not as technicality, but as a substantive aspect of due process in general. There, courts have recognized only one major exception to the requirement of intent: regulatory measures aimed at public welfare or danger. ${ }^{328}$ Included in these measures are "crimes" like parking and fire code violations. ${ }^{329}$ Courts have been willing to find an exception to intent with these crimes for two primary reasons. First, they are not traditional crimes like assault, theft, and murder. They are new crimes outside of our due process traditions and our general concept of a crime. As the Supreme Court in Morissette $v$. United States explained, these crimes, in contrast to traditional crimes, involve "neglect where the law requires care, or inaction where it imposes a duty." ${ }^{330}$ Thus, unlike traditional crimes, a violation does not turn on the intent of the offender, and rightfully so, as these new crimes pose a danger to society as a whole. In these respects, these crimes are public welfare regulations in a class unto themselves. Second, the "penalties [for public welfare crimes] commonly are relatively small, and conviction does no grave damage to an offender's reputation." ${ }^{331}$ As one court remarked, public welfare breaches are only crimes in name or form, not function. ${ }^{332}$ In other words, the stakes are low enough for the individual and high enough for the public as a whole that dispensing with intent, or at least specific intent, is permissible. With that said, the substantive importance of intent to fairness still leaves courts uneasy to invariably commit to the foregoing exception. As Joseph Kennedy has explained, courts have left open the possibility of limiting the enforcement of intentless regulatory crimes where doing so is necessary to avoid unjust results. ${ }^{333}$

There are other limited instances, outside of regulatory measures, in which courts have approved criminal sanctions in the absence of intent, but these instances tend to be sui generis rather than categorical. For instance, courts have upheld statutory rape laws and automatic weapon possession prohibitions that would incarcerate individuals even though they lacked in-

328. See generally Kennedy, supra note 34 , at 768 (explaining that such crimes "specifie[d] no intent as a necessary element").

329. Morissette v. United States, 342 U.S. 246, 262 n.20 (1952).

330. Id. at 255 .

331. Id. at 256 .

332. Tenement House Dep't v. McDevitt, 215 N.Y. 160, 168 (1915).

333. Kennedy, supra note 34 , at 836 . 
tent to commit a crime. ${ }^{334}$ No clear theory binds these minor exceptions together other than that they touch upon activities that society had deemed far afield of acceptable behavior and, thus, the law places an affirmative obligation on citizens to avoid that behavior. Beyond that, the similarities begin to break down. With automatic weapons, the rationale would appear to be the serious and intrinsic nature they pose. ${ }^{335}$ With statutory rape, punishment is premised on the need to protect a particularly vulnerable group from serious risks of exploitation. $^{336}$

School suspensions and expulsions do not fall within these exceptions, nor are they analogous. School discipline is distinct from public welfare regulation in the activity regulated and the punishment to be imposed. Unlike those driving a car, constructing and maintaining buildings, or providing food to the public, students attending school are under no general or affirmative obligation to protect others from harm. ${ }^{337}$ They owe no duty to inspect their backpacks throughout the day or test the chemical content of the liquid in their water bottle before sharing it with a friend or drinking from it themselves. Nor would such an obligation make sense because, in the absence of intentional misdeeds, there is nothing in their bags or possession that poses any threat of danger or interference with the operation of school. If analogous to anything, the student conduct to be regulated is similar to traditional crimes of violence and theft or modern drug crimes, all of which, then and now, require intent as a matter of due process.

Most important, the punishment imposed on students is not minor. Zero tolerance and harsh discipline deprive students not just of the property right considered in Goss, but of a constitutional right recognized by numerous state courts. ${ }^{338}$ Moreover, both the deprivation and the effects are often long-term.

334. Pelliccioni, supra note 324 , at $997-1001$.

335. Id. at 1000.

336. Id. at $997-98$.

337. $C f$. DAN B. DOBBS, THE LAW OF TORTS $\S 414$ (2000) (articulating the no duty rule for defamation).

338. See King ex rel. Harvey-Barrow v. Beaufort Cnty. Bd. of Educ., 704 S.E.2d 259, 260-61 (N.C. 2010); Phillip Leon M. ex rel. J.P.M. v. Greenbrier Cnty. Bd. of Educ., 484 S.E.2d 909, 911 (W. Va. 1996). See generally Michael A. Rebell, Poverty, "Meaningful" Educational Opportunity, and the Necessary Role of the Courts, 85 N.C. L. REV. 1467, 1500-05 (2007) (discussing the requirements of a constitutionally-guaranteed adequate public school education). 
Zero tolerance policies exclude students from school for extended periods of time and, in practice, function as the equivalent of an educational death penalty for many students. ${ }^{339}$ To reiterate the Fifth Circuit, expulsion is "the extreme" and "ultimate punishment," stretching to the outer bounds of the educational systems' "power to act" and harm students. ${ }^{340}$ For these reasons, courts during the immediate pre- and post-Goss years were particularly concerned with schools' substantive justifications for expelling students. ${ }^{341}$ The holdings in those cases are entirely inconsistent with any notion that expulsion is a minor punishment or the nature of student behavior justifies a public welfare approach. Some argue that activities like weapons and drugs pose such a serious threat to schools that rigid lines must be drawn in the sand. ${ }^{342}$ Judge Suhrheinrich in dissent in Seal wrote: "[S]chools act in loco parentis. Given this enormous responsibility, and the potentially devastating consequences of weapons on campus, a strict weapons policy is rationally related to a legitimate government interest-protecting our children from the very real threat of violence. ${ }^{\prime 43}$ This rationale draws on both the public welfare exception and those sui generis exceptions that pertain to extreme dangers or circumstances, but zero tolerance fits in neither.

Judge Suhrheinrich, like others, is conflating the schools' duty with students' duty. One might marshal a public welfare argument for holding a school liable for students' safety, regardless of the school's intent, but the same is not true of holding students accountable. As noted above, students do not owe any affirmative duty to their peers. The fact that the government may owe such a duty does not provide a basis for imposing discipline on students who may lack intent and would otherwise be protected by due process. Moreover, even if students

339. I would concede that schools might be given more leeway with less serious punishments like limited in-school suspension or writing "penalties," although, even here, one struggles with the justification for punishing the innocent if the activity regulated is distinct from traditional public welfare crimes.

340. Lee v. Macon Cnty. Bd. of Educ., 490 F.2d 458, 460 (5th Cir. 1974).

341. See, e.g., C.L.S. v. Hoover Bd. of Educ., 594 So. 2d 138, 139 (Ala. Civ. App. 1991). See generally ARUM, supra note 85, at 120 (explaining that earlier courts indicated that age, past behavior, school performance, and actual disruption of current behavior are important considerations in expulsion decisions).

342. See Blumenson \& Nilsen, supra note 18, at 79-80.

343. Seal v. Morgan, 229 F.3d 567, 582 (6th Cir. 2000) (Suhrheinrich, J., dissenting). 
had an affirmative duty, the public welfare exemption is premised on low level punishment of an "unintentional violator," not the ultimate punishments schools are imposing.

Schools can make a stronger argument that the risk of weapons and drugs to students is equivalent to the risk that automatic weapons, for instance, pose to society. The comparison, however, rests more on sensationalism and emotional appeals than reality. For instance, Judge Suhrheinrich points to a high profile shooting to justify the disregard for intent, writing, "The Columbine High School massacre and other school shootings have, unfortunately, become part of the national consciousness. " ${ }^{445}$ Events such as these, however, are isolated. Schools remain one of the safest places a student can be. ${ }^{346}$ This is not to say that events like Columbine should be ignored. Schools are certainly rational in implementing preventative measures. But it does not follow that a district should disregard intent. School shootings arise not from accidental or even neglectful actions on the part of a student, but from calculated intentional actions.

Even if one allowed that Columbine justified intentless zero tolerance toward firearms, Columbine would not justify the same toward, for instance, fingernail clippers and butter knives. The exceptions to intent are narrow. In the criminal context, for instance, strict liability applies only to a subclass of distinctively and unusually dangerous weapons, not to weapons in general. ${ }^{347}$ Thus, at best, schools might disregard intent for firearms, but no justification could be marshalled in regard to other items that are generally benign simply because they could theoretically be used as weapons. The same problem would arise with regard to schools' broad definitions of drugs.

In sum, while a court owes general deference to schools in the administration of discipline, a court need not afford any on the question of intent. As the rationale of Seal and our legal history demonstrates, substantive due process presumes the requirement of intent. Courts have recognized only a narrow class of specified exceptions. Thus, the burden falls on the educational system to justify any exemption to intent it might seek. Placing that burden on schools, moreover, is not contrary to the deference generally owed to schools in the administration

344. See supra notes 328-33 and accompanying text.

345. Seal, 229 F.3d at 582 (Suhrheinrich, J., dissenting).

346. Majd, supra note 60, at 360-61.

347. Pelliccioni, supra note 324 , at 1000-01. 
of discipline. ${ }^{348}$ General deference is not intended as a license for schools to enact any rules they see fit, so long as they can articulate a rationale that they subjectively believe to be correct. To sanction all such rules would, in the words of the court in Seal, allow a school to "insulate itself even from rational basis review." ${ }^{349}$ When schools adopt or apply rules that are facially inconsistent with substantive due process principles, the burden rightly falls on them to justify the rules. Presently, no justifications other than sensationalized danger-and the notion that hard lines are necessary to protect against it-can be offered in defense of zero tolerance policies that disregard intent. Both of those justifications fail.

\section{Culpability}

The second factor a school must consider in imposing student discipline is culpability. While there may be certain circumstances in which culpability is not germane, those circumstances, as with the requirement of intent, are exceptions to the general rule. The concept of culpability is found throughout our criminal codes, civil liability, and other forms of punishment. For instance, an intentional, calculated murder is fundamentally distinct from a bar-room brawl that ends in death. ${ }^{350}$ Killing someone in self-defense is fundamentally different from both. ${ }^{351}$ All might involve the intentional act of killing another person, but each has a different level of culpability. Thus, the stateauthorized punishment, to the extent there is punishment, is different for each, in both civil and criminal contexts. ${ }^{352}$

The law also recognizes that while individuals might act with the same type of intent, they may have different capacities, which alters the individual's culpability. For instance, the law tends to punish, criminally and civilly, children and adults with diminished mental capacity differently than adults with full capacity, although the exception for adults with diminished capacity is far more limited. ${ }^{353}$ Regardless, the premise of the

348. See Wood v. Strickland, 420 U.S. 308, 326 (1975) (indicating that courts are not to second-guess schools).

349. Seal, 229 F.3d at 579.

350. See generally Kyron Huigens, The Continuity of Justification Defenses, 2009 U. ILL. L. REV. 627 (2009).

351. Id. at 645 .

352. Id. at 681 .

353. See, e.g., DoBBS, supra note 337, at 293 (finding that negligence law holds children to a standard of care based on their age, intelligence, and experience). 
distinctions based on capacity is that legal consequences are justified not simply on an individual's actions or intent alone, but on the individual's responsibility for those actions. Responsibility tends to diminish when an individual's mental capacity is diminished, ${ }^{354}$ the individual lacks realistic options to act differently ${ }^{355}$ or the individual is compelled or persuaded to act for otherwise legitimate reasons. ${ }^{356}$ The law accounts for these factors not because individuals with diminished capacity are innocent in any absolute sense (as is the case when intent is entirely lacking), but because they are the functional equivalent of innocent or, at least, dissimilarly situated from the prototypical offender. ${ }^{357}$ In this respect, punishing individuals with diminished mental capacity does little, if anything, to serve the law's objectives, particularly in criminal law. ${ }^{358}$ When punishment serves no purpose, punishment is constitutionally irrational, or rather violates substantive due process.

\section{a. Minors' Diminished Capacity}

Most pertinent to this Article, children as a class have diminished mental capacity, and thus the law treats them differently than adults. ${ }^{359}$ On the criminal side, the law places juveniles in an entirely different category from adults and limits the punishment they can receive. ${ }^{360}$ On the civil side, the law

354. See, e.g., Alan Brownstein, The Constitutionalization of Self-Defense in Tort and Criminal Law, Grammatically-Correct Originalism, and Other Second Amendment Musings, 60 HASTINGS L.J. 1205, 1235-36 (2009) (discussing the consideration of a defendant's subjective belief of imminent harm with regard to determining whether the defendant acted in self-defense); see also infra notes 359-362 and accompanying text.

355. "The rationale of the [duress] defense is . . the defendant ... avoided a harm of greater magnitude." WAYNE R. LAFAVE \& AUSTIN W. SCOTT, JR., CRIMINAL LAW 433 (2d ed. 1986). However, Lafave and Scott do not describe necessity as negating the mens rea, but as a public policy to not punish where the higher good is served by violations of the law. Id.

356. See Ploof v. Putnam, 71 A. 188, 189 (Vt. 1908) (finding that necessity justifies entries upon land which otherwise would be trespasses).

357. See generally James W. Ellis \& Ruth A. Luckasson, Mentally Retarded Criminal Defendants, 53 GEO. WASH. L. REV. 414 (1985) (discussing the justifications and defenses for criminally punishing the mentally ill and mentally retarded); Herbert Fingarette, Disabilities of Mind and Criminal Responsibility-A Unitary Doctrine, 76 COLUM. L. REV. 236 (1976) (same).

358. LAFAVE \& SCOTT, supra note 355 , at 305.

359. See Brown, supra note 133, at 938 (reviewing studies of students' decision-making processes, maturity, and intellectual development across ages).

360. See generally Sarah M. Cotton, Comment, When the Punishment Cannot Fit the Crime: The Case for Reforming the Juvenile Justice System, 52 ARK. 
limits the types of legal obligations that can be placed on a minor, ${ }^{361}$ and considers age in assessing the liabilities it might impose. $^{362}$ The most instructive analysis of minors' culpability comes from the Court's recent decision in Roper $v$. Simmons, ${ }^{363}$ where the Court held that sentencing juveniles to death is unconstitutional. ${ }^{364}$ The Court forwarded three major distinctions between juveniles and adults that made juveniles inappropriate subjects for such harsh punishment. First:

[A]s any parent knows and as the scientific and sociological studies respondent and his amici cite tend to confirm, "[a] lack of maturity and an underdeveloped sense of responsibility are found in youth more often than in adults and are more understandable among the young. These qualities often result in impetuous and ill-considered actions and decisions." ${ }^{365}$

Second, "juveniles are more vulnerable or susceptible to negative influences and outside pressures, including peer pressure, ${ }^{366}$ which makes it more difficult for them to extricate themselves from negative circumstances that lead to bad behavior. Third, juveniles' character is undergoing development, and thus their character is neither fixed as good or bad.

These three distinctions led the Court to conclude that, regardless of their behavior, juveniles cannot be counted among the "worst offenders" and, thus, do not warrant ultimate sanctions. ${ }^{368}$

The susceptibility of juveniles to immature and irresponsible behavior means "their irresponsible conduct is not as morally reprehensible as that of an adult." Their own vulnerability and comparative lack of control over their immediate surroundings mean juveniles have a greater claim than adults to be forgiven for failing to escape negative influences in their whole environment. The reality that juveniles still struggle to define their identity means it is less supportable to con-

L. REV. 563 (1999) (discussing why the juvenile justice system needs to be reformed and considerations reformers should take into account).

361. See, e.g., Cheryl B. Preston \& Brandon T. Crowther, Infancy Doctrine Inquiries, 52 SANTA CLARA L. REV. 47, 50 (2012) (discussing the infancy doctrine in contracts).

362. See, e.g., DoBBS, supra note 337, at 293 (finding that negligence law holds children to a standard of care based on their age, intelligence, and experience).

363. 543 U.S. 551 (2005).

364. Id. at 578 .

365. Id. at 569 (citing Johnson v. Texas, 509 U.S. 305, 367 (1993)); see also Eddings v. Oklahoma, 455 U.S. 104, 116 (1982) ("Even the normal 16-year-old customarily lacks the maturity of an adult.").

366. Roper, 543 U.S. at 569.

367. Id. at 601 (O'Connor, J., dissenting).

368. Id. at 569 (majority opinion). 
clude that even a heinous crime committed by a juvenile is evidence of irretrievably depraved character. From a moral standpoint it would be misguided to equate the failings of a minor with those of an adult, for a greater possibility exists that a minor's character deficiencies will be reformed. ${ }^{369}$

For these same reasons, neither deterrence nor retribution is served by executing juveniles. ${ }^{370}$

The Court's holding in Roper was based on the Eighth Amendment, but its rationale is equally compelling in regard to harsh forms of school discipline. Relying on Roper and the social science supporting the case's outcome, the report Are Zero Tolerance Policies Effective in the Schools? concludes:

There can be no doubt that many incidents that result in disciplinary infractions at the secondary level are due to poor judgment on the part of the adolescent involved. But if that judgment is the result of developmental or neurological immaturity, and if the resulting behavior does not pose a threat to safety, weighing the importance of a particular consequence against the long-term negative consequences of zero tolerance policies must be viewed as a complex decision, especially since adolescents appear to be more developmentally susceptible to such lapses in judgment. ${ }^{371}$

Josie Brown does not argue that the rationale of Roper bars the use of expulsion or long-term suspension, but that, insofar as culpability is a relevant factor, it must be taken into account, at the very least, with regard to the most severe forms of punishment. ${ }^{372}$

The Court's recent substantive due process precedent regarding civil penalties makes the case for extending the culpability rationale and analysis from Roper to school discipline even more compelling. In a series of cases that comprise the only pertinent substantive due process precedent in recent years, the Court has held that punitive damage awards that are "grossly excessive" in relation to the state's interest "enter the zone of arbitrariness that violates the Due Process Clause."373 The Court articulated a three-factor standard in $B M W v$. Gore $^{374}$ for assessing whether a damage award is grossly excessive: the reprehensibility of the defendant's conduct, the dispar-

369. Id. at 570 (citations omitted) (quoting Thompson v. Oklahoma, 487 U.S. 815, 835 (1988)).

370. Id. at 571 .

371. AM. PSYCHOLOGICAL ASS'N ZERO TOLERANCE TASK FORCE, supra note 290, at 68, quoted in Brown, supra note 133, at 969.

372. Id. at $931-32$.

373. BMW of N. Am., Inc. v. Gore, 517 U.S. 559, 568 (1996); see also State Farm Mut. Auto. Ins. Co. v. Campbell, 538 U.S. 408, 416 (2003).

374. 517 U.S. 559 (1996). 
ity between the actual harm caused and the punitive damages awarded, and the difference between the punitive damages in the instant case and the criminal or civil penalties imposed in comparable cases. ${ }^{375}$ The Court emphasized that "[p]erhaps the most important indicium of the reasonableness of a punitive damages award is the degree of reprehensibility of the defendant's conduct.... [E]xemplary damages ... should reflect 'the enormity of his offense." ${ }^{376}$ The Court has since reiterated and reinforced this approach in other cases. ${ }^{377}$

Roper's culpability rationale and evidence fall squarely within BMW's substantive due process limits on punishment, particularly the reprehensibility factor. Together the cases reflect, at least, three broad principles. First, culpability cannot be disregarded in assigning criminal or civil penalties. Second, the lack of serious culpability is dispositive where the punishment to be imposed is also serious. Third, penalties should be rationally, although not precisely, proportional to culpability, even when the punishment is not extreme or ultimate.

\section{b. Applying Culpability Analysis to School Discipline}

If substantive due process operates to limit monetary harms (which relatively speaking are minor) and the social science in Roper is generally applicable to minors, the foregoing principles should follow in school discipline. Cutting against the application of these principles to other contexts, however, is the fact that Roper, $B M W$, and $B M W$ 's progeny involved penalties at the extreme of their respective paradigms. ${ }^{378}$ To apply a stringent proportionality principle to all punishments could place the courts in the position of a super legislature exercising continual and final review of all criminal and civil punishments, which the Court has consistently made clear it will not do. ${ }^{379}$ Thus, one could read the principles in the case not as generally applicable standards for all punishment-from the minor to the serious-but rather as limits on extreme outliers.

375. Id. at $575,580,583$.

376. Id. at 575 (quoting Day v. Woodworth, 13 How. 363, 371 (1852)).

377. See, e.g., State Farm, 538 U.S. 408.

378. $B M W$ involved $\$ 2$ million in punitive damages compared to $\$ 4,000$ in actual damages. BMW, 517 U.S. at 563, 565, 567. State Farm involved $\$ 145$ million in punitive damages compared to $\$ 1$ million in actual damages. State Farm, 538 U.S. at 412.

379. Tracy A. Thomas, Proportionality and the Supreme Court's Jurisprudence of Remedies, 59 HASTINGS L.J. 73, 134-35 (2007); see also Wood v. Strickland, 420 U.S. 308, 326 (1975). 
A fair reading of the cases and context suggests that the foregoing culpability and proportionality principles extend beyond the immediate context of those cases, but the principles do not operate as broad limitations on every punishment that the state might impose. First, the Court's proportionality principle in $B M W$ contains its own self-limitation, which protects the decision from the problem of overreaching. As Professor Brown emphasizes:

[T] he Court has looked for referents or comparators to gauge the fit between punishment and conduct. The focal point of the Court's disproportionality concern may be what is deemed an unacceptable deviation between the punishment imposed under the challenged regime and the lesser punishment that would be imposed for functionally indistinguishable conduct dealt with under a parallel sanction regime of the same sovereign. ${ }^{380}$

In this respect, the Court is not exercising its own policy preference as to punishment, but following the state's own broader punishment scheme. Second, as a practical matter, the other two principles relating to culpability would not provide a basis for judicial review of most punishments. Only where the state ignored culpability altogether or imposed serious punishment for minor behavior would they be implicated. Because culpability is so rooted in our traditions, the state rarely ignores it. Because extreme punishments are by their nature the exception, the state rarely imposes them.

Even if those principles were not applicable across all paradigms, zero tolerance and harsh school discipline present a compelling context in which to apply them. Like Roper and the $B M W$ line of cases, zero tolerance and expulsion involve extreme punishment: educational death penalties or second-class citizenship, as this Article and the Fifth Circuit, respectively, term it. ${ }^{381}$ As such, zero tolerance and harsh discipline fit within even a narrow reading of those cases' applicability. The issue of culpability, likewise, provides a strong basis for extending the rationale of those cases. Student misbehavior is a result of the same neurological immaturity and social environment determinism involved in Roper, which diminishes student culpability for whatever misbehavior a student is alleged to have committed. Thus, zero tolerance and expulsion involve serious punishment of individuals where serious culpability is likely lacking. Yet, zero tolerance generally ignores the issue of culpability altogether, meaning that schools have not engaged in

380. Brown, supra note 133 , at 979.

381. See supra notes 338-40 and accompanying text. 
any assessment of individual students' culpability, which might otherwise justify judicial deference to a school. In short, judicial intervention in zero tolerance does not require an expansive interpretation of $B M W$ 's holding or Roper's culpability rationale, nor a disregard for schools' judgment.

Applying the other two explicit substantive due process factors articulated in $B M W$-actual harm in relationship to the punishment, and analogous punishments in other contexts ${ }^{382}$ reveal that various applications of zero tolerance and expulsion are not even close to falling within the bounds of permissible punishment. First, harm frequently does not exist. Students with fingernail clippers and cough drops or Mr. Ratner, whom the school admitted was no danger and did the right thing, ${ }^{383}$ cause absolutely no harm to the educational environment, nor do they pose a realistic threat of danger in the future. When the actual harm is compared to the punishment, per $B M W$ 's approach, long-term suspension is necessarily grossly disproportionate. As the concurring judge in Ratner wrote, school officials "jettison[ed] the common sense idea that a person's punishment should fit his crime in favor of a single harsh punishment, namely, mandatory school suspension. Such a policy has stripped away judgment and discretion on the part of those administering it...."384 Ratner's expulsion "is a calculated overkill when the punishment is considered in light of Ratner's good-faith intentions and his, at best, if at all, technical violation of the school's policy." 385

Second, a comparison of potential punishments outside of school to those inside school also demonstrates the gross disproportionality of applying zero tolerance to students with minimal culpability. In fact, identifying an analog punishment outside of school is difficult because zero tolerance frequently punishes behavior for which there would have been no punishment had it occurred anywhere else. For instance, one would be hard pressed to identify a place in society where a minor could not take nail clippers other than school. A student could freely take them onto an airplane-one of the most heavily regulated areas in society and the locus from whence we suffered one of

382. See supra notes 374-76 and accompanying text.

383. See supra notes 221-27 and accompanying text.

384. Ratner v. Loudon Cnty. Pub. Sch., 16 F. App'x 140, 143 (4th Cir. 2001) (Hamilton, J., concurring) (per curiam).

385. Id. at 144 . 
our greatest national tragedies in history. ${ }^{386}$ Even where some relatively benign activity or item might be prohibited in society, the response outside of school would be to take the item or stop the behavior, not harshly penalize it. The only context in which relatively benign activities or possessions might lead to punishment is prison, but prisoners have already committed crimes and forfeited certain liberty and property rights, and the Supreme Court has directly rejected the notion that schools and students are the equivalent of prisons and prisoners. ${ }^{387}$ To the contrary, the Court has repeatedly found that students do not shed their constitutional rights at the schoolhouse door, and impositions on their rights require some justification. ${ }^{388}$ In short, it is hard to articulate any basis-much less a compelling one-under the $B M W$ three-factor analysis to validate the broad application of zero tolerance and harsh discipline.

The debate in regard to applying BMW's holding and Roper's rationale to school discipline should not be whether to apply it, but how far. The underlying social science in Roper, along with common sense, suggests that substantive due process culpability concerns could and should apply more broadly in school discipline than they do in regard to criminal and civil law in general. Aside from older teenagers who intentionally engage in the most serious behaviors, such as bringing a handgun to school, expulsion is a grossly disproportionate and irrational response to student misbehavior, even when the behavior is serious, and particularly when it is not. An elementary school student who brings an actual weapon to school, for instance, may have no appreciation of what he has done. ${ }^{389} \mathrm{His}$ conduct is no doubt serious, but to the extent his culpability is non-existent, total deprivation of his education is disproportionate by $B M W$ and Roper's rationale.

386. TSA Issues Guidelines to Help Passengers Through Security and Expands List of Prohibited Items, TRANSP. SECURITY ADMIN. (Apr. 30, 2002), http://www.tsa.gov/press/releases/2002/04/30/tsa-issues-guidelines-help -passengers-through-security-and-expands-list.

387. See, e.g., New Jersey v. T.L.O., 469 U.S. 325, 338-39 (1985); Tinker v. Des Moines Indep. Cmty. Sch. Dist., 393 U.S. 503, 511 (1968) (holding that public schools cannot be "enclaves of totalitarianism").

388. See, e.g., T.L.O., 469 U.S. at 338; Goss v. Lopez, 419 U.S. 565, 574 (1975); Tinker, 393 U.S. at 506.

389. See generally PENNY HOLland, We DON'T Play WITH GUNS HERE: WAR, WEAPON AND SUPERHERO PLAY IN THE EARLY YEARS (2003). 


\section{c. Culpability Is Lacking with Minor Misbehavior}

Outside of serious behavior like weapons and drugs, all other misbehaviors by students are entirely normal and to be expected. Adolescents as a class are impulsive, lack self-control, need attention, do not always engage in a conscious decisionmaking process, and do not fully appreciate the consequences of their actions. ${ }^{390}$ Thus, nearly every student will, at some point, engage in disruptive classroom behavior by talking out of turn, whispering in class, passing a note, and even responding to a teacher in a way that can be construed as disrespectful. In fact, a reasonable observer might be concerned about a student who was quiet or withdrawn and never excited enough to breach some minor rule of classroom, playground, or hallway decorum. None of this is to say that classroom disruption should go unaddressed. One of the primary purposes and functions of school is to shape and model good behavior. ${ }^{391}$ But the mandatory expulsion of such students borders on sadistic.

A disruptive student has not engaged in aberrational behavior, may not have acted with any disruptive intent, does not pose a danger to others, and does not necessarily pose any more risk of future disruption than any other student. Expelling a disruptive student would certainly frighten and deter those students with sufficient self-control to steer far clear of problematic behavior, but it would do little for students who lack perfect self-control. Recognizing as much, federal special education law places specific limits and prohibitions on the suspension of students whose misbehavior is to be expected based on, for instance, an emotional or behavioral disability. ${ }^{392}$ At the other end of the spectrum, even among those with perfect selfcontrol, a percentage will predictably misbehave anyway as a

390. See Bonnie L. Halpern-Felsher \& Elizabeth Cauffman, Costs and Benefits of a Decision: Decision-Making Competence in Adolescents and Adults, 22 J. APPLIED DEVELOPMENTAL PSYCHOL. 257, 268-69 (2001).

391. See Bethel Sch. Dist. v. Fraser, 478 U.S. 675, 681 (1986) ("[P]ublic education must prepare pupils for citizenship ... . It must inculcate the habits and manners of civility as values in themselves conducive to happiness and as indispensable to the practice of self-government in the community and the nation." (quoting CHARLES A. BEARD \& MARY R. BEARD, THE BEARDS' NEW BASIC HISTORY OF THE UNITED STATES 228 (1968))); Bd. of Educ. v. Pico, 457 U.S. 853, 864 (1982) ("We have also acknowledged that public schools are vitally important... vehicles for "inculcating fundamental values necessary to the maintenance of a democratic political system." (quoting Ambach v. Norwick, 441 U.S. 68, 76-77 (1979))).

392. 20 U.S.C. $\S \S 1412(\mathrm{a})(1)(\mathrm{A}), 1415(\mathrm{k})(1)(2012)$. 
protest to the schools' irrational overkill. ${ }^{393}$ In short, expelling disruptive students borders on punishment for the sake of punishment, not for any legitimate educational goal, because these students' culpability is generally low. ${ }^{394}$

Although more controversial, data and social science would indicate that some misbehavior is a product of the school rather than inherent student characteristics and culpability. A full exploration of this premise is worthy of its own article. Here, it suffices to state the basic findings and rationale. Schools that fail to meet their obligations in delivering a quality educationor are otherwise dysfunctional in terms of administration and teaching-are the schools with the highest suspension and expulsion rates. ${ }^{395}$ Moreover, the failure to deliver a quality education is not just a pedagogical failure, but a state constitutional and federal statutory failure. ${ }^{396}$ The key question here is one of causation. The troubled schools would argue that students are not receiving a quality education because other students are interfering and must be removed from school. Students would tend to argue that excessive misbehavior occurs because the schools are ineffective.

Data and social science studies tend to support the students. Studies show that the same student acts differently in different classrooms, revealing a strong correlation between effective classroom management and educational outcomes. ${ }^{397}$ Likewise, "when students transferred from a school with a high dropout rate to one with a low dropout rate, their behavior tended to conform to the low rate," which negates the notion that good or bad behavior emanates from the "inherent characteristics of students." ${ }^{398}$ Moreover, contrary to some schools' po-

393. ARUM, supra note 85 , at 181-82 (discussing students' perception of overly strict discipline and how it can exacerbate student misbehavior rather than deter it).

394. See generally KAFKA, supra note 11, at 120 ("Rather than teach students appropriate habits of body and mind, zero tolerance policies are intended strictly to punish ....").

395. KIM ET AL., supra note 75, at 9, 18.

396. See No Child Left Behind Act of 2001, 20 U.S.C. $\$ \S 6301,6311$ (2012) (mandating the teaching of core subjects and one hundred percent proficiency in them); Allen W. Hubsch, Education and Self-Government: The Right to Education Under State Constitutional Law, 18 J.L. \& EDUC. 93, 96-97 (1989) (stating that all fifty states constitutionally guarantee education); Rebell, supra note 338 , at 1527 (stating that a majority of state courts have held that the state must provide an equitable and/or adequate education).

397. See LOSEN \& MARTINEZ, supra note 9, at 2.

398. Dona M. Kagan, How Schools Alienate Students at Risk: A Model for 
sition that their high rates of discipline are necessary to maintain any semblance of order, punishing students in a dysfunctional education setting only makes matters worse and takes more students further off track. ${ }^{399}$

Hollingsworth, Lufler, and Clune summarize the research on this point with the simple statement: "[S]chools which are bad end up punishing their students." ${ }^{400}$ None of this is to suggest that schools should take all the blame and students none, nor that expulsions are off-limits in these schools. Rather, the point is that where a school is failing to deliver its constitutionally and statutorily mandated educational quality, it bears some culpability for students' misbehavior. Given that students as a class have diminished culpability regardless of environment, only a totalitarian or arbitrary state would harshly punish students in the context of a legally and pedagogically deficient environment, without even accounting for culpability.

\section{Harm}

Implicit in the foregoing Sections on intent and culpability is the notion that the seriousness of a student's behavior and the potential ongoing danger or disruption the student poses are necessarily relevant to discipline. The basis and justification upon which a district entirely excludes a student from school is not simply that the student has done something he or she has been instructed to avoid. A standard as bare as that would be no less than totalitarianism and constitutionally infirm unless some other legitimate objective could be identified. ${ }^{401}$ The legitimate basis and justification is that the student has harmed or poses some harm to the educational environment, either in terms of physical danger and disruptive behavior, or that punishment would prevent or deter that behavior in the first instance. Either way, the goal must be tethered to real or potential threats. ${ }^{402}$

Examining Proximal Classroom Variables, 25 EDUC. PSYCHOLOGIST 105, 107 (1990) (citing Porter W. Sexton, Trying To Make It Real Compared to What? Implications of High School Dropout Statistics, 5 J. EDUC. EQUITY \& LEADERSHIP 92 (1985)).

399. HOLLINGSWORTH ET AL., supra note 134, at 19.

400. Id. at 18 .

401. See generally RE-THEORIZING Discipline In EdUCATION: Problems, Politics \& Possibilities 4 (Zsuzsa Millei et al. eds., 2010) (discussing the problem of totalitarianism in discipline).

402. As the Court in BMW of North America v. Gore explained:

The sanction imposed in this case cannot be justified on the 
Broad zero tolerance policies do the opposite, seriously punishing students who may pose no threat. They expel or suspend the elementary students with a pair of fingernail clippers, the middle school student saving his friend from potential suicide, and the cub scout who uses his favorite utensil to spread butter on his sandwich. ${ }^{403}$ If the rationale for expulsion is danger, it is irrational to expel these students. If it is deterrence, it is still irrational because the punishment sweeps too far afield of intent, culpability, and danger to be related to the deterrence of students who actually pose a danger. ${ }^{404}$

When pressed on these points, zero tolerance advocates have responded with varying simplistic versions of "the rules are the rules" and the only way to ensure safety and order is to enforce the rules in existence. Districts insist that they must draw hard lines in the sand and have no choice but to expel students when they cross them. ${ }^{405}$ This line of reasoning presupposes the existence of a sufficient justification for rules and punishment, when rules and punishment are not, in fact, selfvalidating or self-rationalizing. Line drawing is not a justification in itself. That a rule is written down and demands allegiance may address a procedural point, but it does not answer the underlying issue of whether the rule is valid in substance. ${ }^{406}$

ground that it was necessary to deter future misconduct without considering whether less drastic remedies could be expected to achieve that goal. The fact that a multimillion dollar penalty prompted a change in [the behavior of the defendant or defendant class] sheds no light on the question of whether a lesser deterrent would have adequately protected the interests of [the State]. 517 U.S. 559, 584 (1996).

403. See, e.g., Ratner v. Loudoun Cnty. Pub. Sch., 16 F. App'x 140, 141-42 (4th Cir. 2001) (per curiam); Ian Urbina, It's a Fork, It's a Spoon, It's a... Weapon? School Suspends Boy, 6, N.Y. TIMES, Oct. 12, 2009, at A1.

404. See BMW, 517 U.S. at 584-85 (rejecting a damage award, even if it achieved the state's deterrent goals, because some lesser award may have done the same).

405. Seal v. Morgan, 229 F.3d 567, 578 (6th Cir. 2000); Troyan, supra note 66 , at $1640-42$.

406.

[A school district] may not hide behind the notion that the law prohibits leniency for there is no such law. Individualized punishment by reference to all relevant facts and circumstances regarding the offense and the offender is a hallmark of our criminal justice system. In a system where criminal offenders are afforded individualized punishment upon review of the facts and circumstances regarding the offense, students in our public school systems, who may also face a daunting punishment, should at least be afforded a thorough review of their case, prior to imposition of penalty. 
For the underlying rule to be valid, it must be based on a proper goal and consider the necessary factors discussed herein. ${ }^{40}$

\section{E. The PREsupposition of Key INQUIRIEs Is PROHIBITED}

Finally, due process prohibits decision-makers from deciding students' fates in advance, and requires that they listen to what the students say, deliberate the facts, and determine whether further information is necessary before making a decision. ${ }^{408}$ This principle is both substantive and procedural. It is

Colvin ex rel. Colvin v. Lowndes Cnty., Miss. Sch. Dist., 114 F. Supp. 2d 504, 512 (N.D. Miss. 1999) (citation omitted).

407. Id. at $512-13$.

408. See, e.g., id. An analogous problem recently arose in Miller v. Alabama, 132 S. Ct. 2455 (2012), and its aftermath. The Court held that mandatory life without parole for juvenile homicide offenders violated the Eighth Amendment. Id. at 2457-58. The open question following the case was whether the holding simply requires some discretion in the life without parole decision or whether there has to be an individualized sentencing hearing where certain factors are considered. Most courts have found that it requires an individualized hearing. See, e.g., People v. Siackasorn, 149 Cal. Rptr. 3d 918, 922 (Dist. Ct. App. 2012) ("[Miller requires that] a 'sentencer' ('judge or jury') 'follow a certain process' before imposing this harshest possible penalty on a juvenile offender: i.e., consider the offender's youth and the hallmark features of youth (among them, immaturity, impetuosity, and failure to appreciate risks and consequences); and consider, in an individualized way, the nature of the offender and the offense (for example, as relevant, the offender's background and upbringing, mental and emotional development, and possibility of rehabilitation).”); Daugherty v. State, 96 So. 3d 1076, 1079 (Fl. Dist. Ct. App. 2012) ("[U]nder Miller, judges must take an individualized approach to sentencing juveniles in homicide cases and consider factors which predict whether a juvenile is amenable to reform or beyond salvation."); State v. Bennett, 820 N.W.2d 769, 2012 WL 2816806, at*4 (Iowa Ct. App. 2012) (unpublished table decision) ("[Miller] requires that prior to sentencing a juvenile to life without parole, the sentencing court take into consideration all pertinent factorsnamely an offender's status as a juvenile and the numerous characteristics that accompany this status."); State v. Williams, 2012-1766, p. 1 (La. 3/8/13); 108 So. 3d 1169, 1169 (per curiam) (stating that in light of Miller "we require [the sentencer] to take into account how children are different, and how those differences counsel against irrevocably sentencing them to a lifetime in prison" (internal quotation mark omitted)); Hye v. State, No. 2010-KA-01780-COA, 2013 WL 2303518, at *5 (Miss. Ct. App. May 28, 2013), cert. granted, 131 So. 3d 577 (Miss. 2014) ("The Court in Miller suggested factors to consider when determining whether a juvenile should be sentenced to life or life without parole, including chronological age and its hallmark features, family and home environment, circumstances of the homicide offense, and the possibility of rehabilitation." (internal quotation marks omitted)); Bear Cloud v. State, 2013 WY 18, II 44, 294 P.3d 36, 47 (Wyo. 2013) ("Miller requires an individualized sentencing hearing for every juvenile convicted of first-degree murder at which the sentencing court must consider the individual, the factors of youth, and the nature of the homicide in determining whether to order a sentence that includes the possibility of parole."). These decisions are equally consistent with 
procedural in that it requires particular processes and substantive in that these processes are aimed at producing a meaningful hearing and fair outcome. The substantive principle is breached when the key inquiries to be determined through the due process hearing are decided or significantly prejudiced in advance. ${ }^{409}$ As the Court has explained, a "[p]resumption in favor of the "Government's evidence" does not violate the Constitution, but only so long as that presumption "remain[s] a rebuttable one and fair opportunity for rebuttal [is] provided." ${ }^{410}$ Also, inherent in this statement is that the government has amassed some evidence to create a presumption, rather than having adopted a presumption for its own sake.

Zero tolerance breaches this substantive principal. Many zero tolerance policies effectively operate as irrebuttable presumptions that discipline is warranted. To be clear, laws and regulations frequently operate on presumptions for reasons of fairness, policy, or efficiency. ${ }^{411}$ Doing so does not necessarily raise due process concerns. But when a presumption is irrebuttable, particularly in regard to key aspects of liability, a presumption eliminates the entire substance and purpose of a due process hearing by narrowing the scope of the deliberation too far. Rather than an assessment of action, intent, culpabil-

this Article's early argument that culpability is necessarily relevant in the severe punishment of minors. See supra Part II.B.2.

409. See, e.g., Patterson v. New York, 432 U.S. 197, 210, 215 (1977) (prohibiting the "shifting of the burden of persuasion with respect to [an important] fact"); Cleveland Bd. of Educ. v. LaFleur, 414 U.S. 632, 644-46 (1974); see also John J. Garman \& Ray Walker, The Zero-Tolerance Discipline Plan and Due Process: Elements of a Model Resolving Conflicts Between Discipline and Fairness, 1 FAULKNER L. REV. 289, 298 (2010) (stating that zero tolerance policies operate on a presumption of guilt). The Court's mandatory sentencing guideline cases reveal an analogous problem. There, the government had set up systems whereby the jury would determine guilt based upon a few predicate facts and then leave sentencing to judges, who would also consider certain more complex facts. United States v. Booker, 543 U.S. 220, 227-29 (2005); Blakely v. Washington, 542 U.S. 296, 298-301 (2004). In those cases, the Court found that legislatures cannot legislate certain facts and considerations out of the jury's fact-finding process because those facts are necessarily aspects of the crime that the Sixth Amendment requires a jury to decide. It is the jury's role to be a circuit breaker in the state's machinery of punishment. See, e.g., Booker, 543 U.S. at 226-27, 230; Blakely, 542 U.S. at 305-07. School discipline obviously involves a different context, but the underlying problem is the same: a set of rules that deprive the fact finder from considering key inquiries.

410. Hamdi v. Rumsfeld, 542 U.S. 507, 534 (2004) (plurality opinion).

411. See, e.g., Keyes v. Sch. Dist. No. 1, Denver, Colo., 413 U.S. 189, 208-10 (1973). 
ity, and harm, these inquiries are often merged into a single one: whether an act or event in question occurred. ${ }^{412}$ If, for instance, a weapon was found on a student, many school districts, pursuant to due process, would conduct a hearing in which no issues beyond that fact are considered. As Garman and Walker write, "the basic concept of the zero-tolerance discipline policy is the near-presumption of guilt founded upon a mere statement of fact." ${ }^{, 13}$ From this presumption or finding flows the second and more explicit irrebuttable presumption: that the ultimate sanction of exclusion is per se the appropriate response to a student's behavior. In effect, the school is just going through the motions of process, but has no intention of actually deliberating the facts and issues at hand because it has already decided the outcome. This prejudgment, or sham process, violates due process. ${ }^{414}$

Schools' primary response is that "[e]fficiency calls for swift, decisive discipline that will fix the immediate problem." ${ }^{" 15}$ Efficiency and speed, however, cannot be justifications for thoughtlessness in regard to the facts of a case and presumptions not grounded in reality. Efficiency and speed are justifications for limiting the exact type of process a school will afford, ${ }^{416}$ as more formalized process can be burdensome. They are not legitimate justifications for presuming answers to substantive questions and making the presumptions irrebuttable. As one court reasoned, the aim of due process is:

$[\mathrm{T}]$ o require school boards to fully consider the circumstances surrounding the misdeed as well as the penalty to be prescribed . . . Employing a blanket policy of expulsion, clearly a serious penalty, precludes the use of independent consideration of relevant facts and circumstances. Certainly, an offense may warrant expulsion, but such punishment should only be handed down upon the Board's independent determination that the facts and circumstances meet the requirements for instituting such judgment. ${ }^{417}$

412. See Garman \& Walker, supra note 409, at 302-03, 316.

413. Id. at 298 .

414. See, e.g., In re Murchison, 349 U.S. 133, 136 (1955) ("A fair trial ... requires an absence of actual bias in the trial of cases. But our system of law has always endeavored to prevent even the probability of unfairness."); Moore v. Dempsey, 261 U.S. 86, 91 (1923); see also Reynolds v. United States, 98 U.S. 145, 155 (1878) ("[A] juror who has formed an opinion cannot be impartial.").

415. Troyan, supra note 66, at 1640; see also Wood v. Strickland, 420 U.S. 308, 319 (1975).

416. See Mathews v. Eldridge, 424 U.S. 319, 348 (1976).

417. Colvin ex rel. Colvin v. Lowndes Cnty. Miss. Sch. Dist., 114 F. Supp. 2d 504, 512 (N.D. Miss. 1999). 
In short, while a school or board's judgments are accorded deference, due process requires that those judgments be based on an individualized consideration of inherently relevant facts. No predetermined set of rules or decisions can validly eliminate this adjudicative function. Moreover, without a consideration of, for instance, the harm posed by a student, the basis upon which a student is to be legitimately punished falls apart. ${ }^{418}$

\section{CONCLUSION}

The prospect of success in challenging zero tolerance and overly harsh discipline has been bleak for some time. Over the past decade, this has meant that approximately three million students per year have been excluded from school and deprived of their statutory and constitutional rights to education. ${ }^{419}$ Once excluded, these students fall into a new high-risk category for subsequent exclusion, academic failure, drop-out, unemployment, and incarceration. Most distressing is the fact that most of these students did nothing more than act out in ways that, although disruptive to school, are not dangerous, serious, or unexpected. Lower courts have done nothing to suggest schools should be deliberate or thoughtful in this process.

Recent decisions by the Supreme Court regarding other constitutional claims by minors, however, suggest that the judicial climate is susceptible to positive change, not because the Court has grown more liberal, but because state actors have grown overzealous in their treatment of minors. In fact, the Court in the past few years has struck down the strip search of a student for Tylenol as too invasive ${ }^{420}$ indicated that the police interrogation of a student at school must be informed by the student's age, ${ }^{421}$ and found that minors are unsuitable for criminal law's ultimate sanction. ${ }^{42}$ In other words, the state has taken the flexibility previously afforded by the Court and abused it or, at least, gone further than the Court is any longer willing to tolerate. Schools have been just as aggressive in their

418. See, e.g., Seal v. Morgan, 229 F.3d 567, 575-76 (6th Cir. 2000); see also CHEMERINSKY, supra note 314 , at 561 (stating that substantive due process requires a legitimate justification for the state's action).

419. Rokeach \& Denvir, supra note 19, at 282.

420. Safford Unified Sch. Dist. No. 1 v. Redding, 557 U.S. 364, 368, 379 (2009).

421. J.D.B. v. North Carolina, 131 S. Ct. 2394, 2399, 2408 (2011).

422. Roper v. Simmons, 543 U.S. 551, 578 (2005); see also Miller v. Alabama, 132 S. Ct. 2455, 2457-58 (2012) (striking down mandatory life without parole for minors). 
zero tolerance and harsh discipline policies, which are the primary impetus for activities like strip searching and interrogating students. Yet, zero tolerance is governed by a separate doctrine that requires a creative and reasonable analytical solution if the courts are to intervene. Serious consideration of the rationality of schools' policies and the substantive due process principles that limit them provides that solution. 